\title{
Shareholder diversification and bank risk-taking
}

DOI:

10.1016/j.jfi.2015.03.001

\section{Document Version}

Accepted author manuscript

Link to publication record in Manchester Research Explorer

\section{Citation for published version (APA):}

Garcia-Kuhnert, Y., Marchica, M. T., \& Mura, R. (2015). Shareholder diversification and bank risk-taking. Journal of Financial Intermediation, 24(4), 602-635. https://doi.org/10.1016/j.jfi.2015.03.001

\section{Published in:}

Journal of Financial Intermediation

\section{Citing this paper}

Please note that where the full-text provided on Manchester Research Explorer is the Author Accepted Manuscript or Proof version this may differ from the final Published version. If citing, it is advised that you check and use the publisher's definitive version.

\section{General rights}

Copyright and moral rights for the publications made accessible in the Research Explorer are retained by the authors and/or other copyright owners and it is a condition of accessing publications that users recognise and abide by the legal requirements associated with these rights.

\section{Takedown policy}

If you believe that this document breaches copyright please refer to the University of Manchester's Takedown Procedures [http://man.ac.uk/04Y6Bo] or contact uml.scholarlycommunications@manchester.ac.uk providing relevant details, so we can investigate your claim.

\section{OPEN ACCESS}




\title{
Shareholder diversification and bank risk-taking
}

\author{
Yamileh García-Kuhnert ${ }^{a}$, Maria-Teresa Marchica ${ }^{\mathrm{b}, *}$, Roberto Mura ${ }^{\mathrm{b}}$ \\ ${ }^{a}$ Central Bank of Dominican Republic, Calle Pedro Henríquez Ureña, esq. Leopoldo Navarro, Santo Domingo, Dominican Republic \\ ${ }^{\mathrm{b}}$ Manchester Business School, Accounting and Finance Division, Booth Street East, Manchester M13 9PL, United Kingdom
}

\section{A R T I C L E I N F O}

\section{Article history:}

Received 17 July 2013

Available online $\mathrm{xxxx}$

Keywords:

Largest shareholder portfolio diversification Bank risk-taking

\begin{abstract}
A B S T R A C T
Using the entire universe of Bankscope and Amadeus Top 250,000 we construct the portfolios of shareholders who hold equity stakes in publicly traded and privately held European banks for each year over the period 1999-2008. We show that about 62\% of banks' ultimate largest shareholders are diversified investors, holding on average equity investments from thirteen companies in their portfolio. We exploit this heterogeneity to investigate the impact of their portfolio diversification on bank risk-taking. Our results show that banks with more diversified shareholders undertake more risks. This relation is both statistically significant and economically sizeable. Overall, these findings contribute to the literature by studying for the first time a specific channel through which financial development, in the form of bank shareholders' diversification, affects the banks' risk-taking decisions.
\end{abstract}

(c) 2015 Elsevier Inc. All rights reserved.

\section{Introduction}

The pivotal role of financial intermediaries in general, and banks in particular, is to choose which firms get to use society's savings (Schumpeter, 1934). This allows the economic system to grow and decreases aggregate volatility by redistributing risks (e.g. Levine, 1997, 2005 for extensive surveys). The recent financial crisis has highlighted the degree to which global economies are exposed to (excessive) risk-taking by banks. ${ }^{1}$ Yet little is known about the drivers behind risk-taking behaviour by banks.

\footnotetext{
* Corresponding author.

E-mail addresses: y.garcia@bancentral.gov.do (Y. García-Kuhnert), maria.marchica@mbs.ac.uk (M.-T. Marchica), roberto. mura@mbs.ac.uk (R. Mura).

1 "The depth and severity of the crisis were amplified by weaknesses in the banking sector such as excessive leverage, inadequate and low quality capital, and insufficient liquidity buffers [...] Moreover, failure to capture major on and off-balance sheet risks, as well as derivative related exposures, was a key factor that amplified the crisis [...]" (Basel Committee on Banking Supervision, 2010, p.4).
} 
In this paper we study a specific determinant of risk-taking, the portfolio diversification of banks' largest shareholders. We provide evidence that banks whose largest shareholders are more diversified take more risks than those whose largest shareholders have relatively less diversified portfolios.

Controlling shareholders who are more diversified generally have stronger incentives to undertake riskier projects. They are less concerned with the firm-specific risk than shareholders who have most of their wealth concentrated in one single firm (Jensen and Meckling, 1976). Parrino et al. (2005) show in their simulations how diversified wealth makes agents less risk averse in taking investment decisions; while Faccio et al. (2011) provide strong empirical evidence of a positive relation between large shareholder portfolio diversification and risk-taking in non-financial companies.

Previous studies in the banking literature have used ownership as a proxy for wealth diversification and often find contrasting results. Saunders et al. (1990) find that (small) increases in managerial stock ownership make managers more closely aligned with shareholder incentives to undertake more risk. Anderson and Fraser (2000) show a negative relation between managerial ownership and bank risktaking only when regulations designed to reduce risk-taking are in place. Knopf and Teall (1996) and Cebenoyan et al. (1999) report an inverse relation between thrift institutions risk-taking and the level of ownership by institutional investors, who are assumed to be diversified shareholders. On the other hand, Barry et al. (2011), Erkens et al. (2012) and Cheng et al. (2015) find a positive association between institutional investors and risk-taking choices. Further, Laeven and Levine (2009) and Beltratti and Stulz (2012) find that bank risk-taking is higher when banks are owned by powerful shareholders with large cash flow rights, who are assumed to be diversified investors.

To our knowledge Sullivan and Spong (2007) is the only work that studies the effect of insiders' personal wealth on risk-taking decisions; their study covers a small sample of US banks between 1993 and 1994. They find that bank earnings volatility decreases when insiders' wealth is more concentrated in the bank they manage. (For an extensive survey of the literature on the corporate governance of banks see de Haan and Vlahu, 2013).

Using the entire universe of Bankscope and Amadeus Top 250,000 we are able to construct the portfolio of the ultimate largest shareholders of publicly traded and privately held European banks for each year over the period 1999-2008. The European banking system is one of the largest among those in the developed economies. In its latest report, the European Banking Federation shows that at the end of 2010 European banks held on average five and six times more assets than the US and Japanese banks respectively. Further, bank deposits compared to total GDP in Europe was reported as $139 \%$, while the same figure was around $59 \%$ in the US and $137 \%$ in Japan. Also, bank loans in Europe were equal to $144 \%$ of GDP, compared with $45 \%$ in the US and $96 \%$ in Japan (European Banking Federation, 2011). ${ }^{2}$ These figures show how the European economy is indeed very heavily bank-oriented. Given the central role played by the banking system in the economy, European data offer an interesting case to investigate and enhance our understanding of the incentives that regulate bank risk-taking decisions.

We provide novel evidence on the level of diversification of large shareholders in the banking sector. We show that bank largest ultimate shareholders hold on average equity investments in thirteen different firms. ${ }^{3}$ Overall, $62 \%$ of shareholders hold investments in at least two companies and some of them $(23 \%)$ do so in ten or more. The average bank largest ultimate shareholder owns almost $39 \%$ (40\%) of the bank's total cash flow rights (control rights), suggesting that, at least in Europe, shareholding in banks is not widely spread. This is consistent with Caprio et al. (2007) and Laeven and Levine (2009). It is thus reasonable to expect that bank largest ultimate shareholders are indeed able to exercise an element of control over the risk-taking choices of the banks they own. ${ }^{4}$ Interestingly, the correlation between portfolio diversification and total cash flow rights is only -0.2 , which suggests some caution should be exercised in using ownership concentration as an inverse proxy for portfolio diversification (similar figures are reported in Faccio et al., 2011).

\footnotetext{
2 The European Banking Federation collects banking sector data from its Members and Associates on an annual basis.

${ }^{3}$ Previous studies report an average of 2.4 stocks held by Finnish individuals (Karhunen and Keloharju, 2001), four to seven by the typical US individual investor (Barber and Odean, 2000; Goetzmann and Kumar, 2008), and about four by the average largest shareholder of non-financial companies in Europe (Faccio et al., 2011).

${ }^{4}$ In fact, all other shareholders hold on average only $4 \%$ of the Cash Flow Rights.
} 
Thanks to the large heterogeneity of our sample we proceed to investigate the role played by large shareholder portfolio diversification in bank risk-taking decisions. We use three main proxies for portfolio diversification: (1) the total number of firms owned directly or indirectly by each bank largest shareholder (No. of firms); (2) the Herfindahl Index of wealth concentration for each largest bank shareholder (HI); (3) the correlation of returns between the different 4-digit US SIC sectors in which the largest shareholder invests (Correlation). The main proxy of bank risk-taking is the Z-score, which represents the probability of insolvency for each bank.

Our tests show that banks with more diversified shareholders tend to undertake riskier decisions. This result is also economically sizeable. Across all proxies of portfolio diversification, a standard deviation increase of portfolio diversification increases the insolvency rate of the average bank by almost 3\%. This figure compares very well with the average impact of all other control variables, around $3.8 \%$, suggesting that portfolio diversification is indeed a primary determinant of bank risk-taking. This result is robust to various controls for the type of largest shareholder, to alternative proxies of risk-taking, portfolio diversification, bank type, and the inclusion of country characteristics that control for the regulations to assess the degree of capital at risk in a bank and to limit banks' non-lending activities.

As is common in many studies in our field, the relation we find could potentially be affected by endogeneity issues. We take a number of steps to control for the potential impact of this problem. First, in all our models we control for other bank-specific characteristics that are likely to affect risk-taking decisions, such as size, leverage, interest margin and interest activity, loan loss provision, listing status, largest shareholder ownership and managerial ownership. Further, portfolio diversification proxies are taken at the year preceding the period over which we calculate bank risk-taking.

Second, we exploit the panel dimension of our sample and run all models including shareholder fixed effects (besides country and year fixed effects), to control for the possibility of omitted variable bias and self-selection. In fact, preferences across shareholders may differ due to traits that we are not able to measure (e.g. age, total non-equity wealth) or to features that are unobservable (e.g. particular forms of the utility function). Omitting such variables may render all explanatory variables in our regressions biased and inconsistent (Wooldridge, 2002). Further, it may be argued that individual preferences of the largest shareholders may induce them to invest in banks that better suit their own preferences to risk. If this were the case, then the causality would run from bank risk-taking to portfolio diversification, not the other way round. Panel data estimations with shareholder fixed effects show that even controlling for omitted variable bias and potential self-selection, largest shareholder portfolio diversification still remains a statistically and economically important determinant of bank risk-taking.

Third, to further address the question whether the largest shareholders do affect the bank risk-taking rather than simply select a bank with a certain risk profile, we exploit the differences in the institutional settings regulating the ownership of banks across countries and perform two different tests. In the first one, we exploit the cross-sectional heterogeneity in the regulatory restrictiveness of ownership of banks. We employ the propensity score-matching procedure to compare the portfolio diversification and risk-taking of a sub-sample of banks in countries with less restrictive regulations on bank ownership to a matched sub-sample of banks in countries with more restrictive regulations. We show that investors in less restrictive countries seem more able/prone to acquire equity stakes in banks and so improve the diversification of their portfolio. More importantly, banks in countries that allow investors to diversify more by holding banks' equity seem to take riskier choices. In the second test, we exploit the change in the regulatory restrictiveness of ownership of banks during our sample period as a quasi-natural experiment that changes the portfolios of some investors. In particular, we focus on changes that make the regulations on ownership of banks more stringent over time, since these are the most frequent events in our sample. We show that on average the portfolio diversification of largest shareholders significantly decreases after the change and so does the risk-taking of the banks they own.

Fourth, we adopt the instrumental variable (IV) technique as an alternative method to address the reverse causality issue. We use two different instruments that should capture the "natural" tendency 
of shareholders to diversify. After controlling for that, we still find that results are similar to the baseline models, that is, a positive and significant relation indicating that shareholders portfolio diversification leads to more bank risk-taking.

Fifth, as a further test to control for potential reverse causality concerns we exploit the event of credit rating downgrade. If reverse causality was likely to explain our previous results, then we would expect a significant change in shareholder portfolio diversification following a bank credit rating downgrade. Instead, we find that following a downgrade there appears to be no significant adjustment in the portfolio diversification of the largest shareholder.

We acknowledge that one cannot fully control for the endogeneity issue. Nonetheless, all our attempts form a consistent body of evidence that portfolio diversification of the largest shareholder leads to banks making decisions that carry a higher risk.

This paper contributes to the existing literature on several levels. First, it provides novel evidence on the structure of governance in the banking sector. Previous studies in banking literature have made different assumptions on the wealth diversification of bank shareholders, often finding contrasting results (e.g. Saunders et al., 1990; Anderson and Fraser, 2000; Knopf and Teall, 1996; Barry et al., 2011; Laeven and Levine, 2009). Evidence in corporate finance literature shows that the average investor in the non-financial sector is only moderately diversified (e.g. Barber and Odean, 2000; Goetzmann and Kumar, 2008; Faccio et al., 2011), holding about four companies in her portfolio. We show that the average bank largest shareholder is rather more diversified than investors in the non-financial firms, holding equity stakes in thirteen different firms. We further show that the average bank largest shareholder has sufficient cash flow rights (39\%) to control bank decisions. When we calculate the correlation between ownership and portfolio diversification we find that, although negative, it seems to be relatively low (about -0.2) suggesting that in our sample we may have shareholders with relatively well diversified portfolios that also hold a large fraction of ownership in a single bank, and vice versa. This may suggest some caution is needed when using ownership concentration as a perfect proxy for portfolio diversification.

Second, we contribute to the strand of research that studies the determinants of bank risk-taking. We show that the largest shareholder portfolio diversification indeed has a positive and economically significant effect on bank risk-taking. In particular, banks controlled by more diversified largest shareholders seem to take riskier decisions than those controlled by undiversified shareholders. This evidence points to the fact that largest shareholders play a non-trivial role in the risk-taking decisions of banks. As such, this may well be relevant and contribute to the recent debate concerning the mechanisms aimed at improving bank risk governance. Further, it highlights how effective the shareholder's trait of portfolio diversification might be in shaping banks decisions.

Third, our paper adds to the vast literature on economic and growth and the role played by banks in the economy. One of the fundamental underpinnings of an efficient capital allocation and sustained economic growth is the ability to undertake profitable but risky opportunities (Acemoglu and Zilibotti, 1997; Baumol et al., 2007; John et al., 2008). The unique advantage of banks of being able to acquire and process information improves the ex-ante assessment of growth opportunities, and therefore makes the allocation of capital more efficient and promotes the economic development (e.g. Boyd and Prescott, 1986; Diamond, 1984; Wurgler, 2000). Numerous studies show that concentrated wealth can bias capital allocation and retard growth in general (see Morck et al., 2005 for an extensive survey). Within the banking system in particular, certain categories of bank shareholders, such as families and the government, seem to correlate with more inefficiency (e.g. La Porta et al., 2002; Morck et al., 2011; Taboada, 2011; Wurgler, 2000). Findings in our paper show an alternative channel - that is, the degree of portfolio diversification of the largest shareholders - through which bank governance may positively affect the real economy. More generally, to the extent that well-functioning financial markets make it easier for investors to obtain diversified portfolios, this evidence shows an alternative way for financial development to affect the real economy.

In the following section we describe the sample and our main variables. In Section 3 we present the main findings and discuss further issues of endogeneity. In Sections 4 and 5 we present a number of robustness tests. Section 6 concludes the paper. 


\section{Data}

Our primary source of data is Bankscope, one of the products of Bureau van Dijk, from which we gather information on both direct ownership and accounting variables for all European privately held and publicly traded banks with at least one year observation over the period 1999-2008. Bankscope is widely used by both academics and practitioners, including central banks (see, for example, Caprio et al., 2007; Demirgüç-Kunt and Huizinga, 2010; Laeven and Levine, 2009; Morck et al., 2011).

As for other Bureau van Dijk products, Bankscope is distributed in DVD format and is issued every month. We use one issue each year. As accounting information is typically incomplete for the year just ended and for the preceding year, we skip the most recent reporting year and collect accounting data retroactively from the 2010 DVD and move progressively backwards in time. ${ }^{5}$ Ownership information, on the other hand, is not provided on a historical basis. So we collect these data for each year from each DVD. Our sample starts from 1999 (as this is the first year for which we can collect ownership information with shareholders' identifiers), and ends in 2008 (as this is the last year for which we construct our risk-taking proxies).

To construct the equity portfolios of each bank largest shareholder, we first need to identify all ultimate shareholders. Bankscope includes worldwide ownership information of financial institutions only. However, a large number of banks are owned by non-financial companies (see, for example, Caprio et al., 2007). We therefore combine Bankscope with ownership data from the entire universe of the Amadeus Top 250,000 database. Amadeus provides both direct ownership (and accounting data) for both privately held and publicly traded European non-financial companies that satisfy a minimum size threshold. ${ }^{6}$ The advantage of using this combined database is that we can trace the ownership of publicly traded, privately held, financial and non-financial companies across several countries.

The ownership data is collected by Bureau van Dijk from different sources: directly from the companies themselves; official bodies (e.g. stock exchanges); or associated information providers (e.g. Jordans for the UK and Ireland; LexisNexis for Netherlands; Novcredit for Italy; Coface for France). Faccio et al. (2011) have assessed the quality of the ownership information included in Amadeus by comparing the stake held by the largest direct shareholders as they appear in Amadeus with the same information from alternative sources. They collected ownership information in three different markets for which it was relatively easy to retrieve this information from online sources: UK, Italy and Spain. Then they computed the correlation coefficient between the ownership of the largest shareholder as reported in Amadeus and that reported in the alternative sources. The overall correlation coefficient is 0.87 .

We further went to great lengths to carefully check and harmonize the identifiers of shareholders across the two databases Bankscope and Amadeus.

In addition, we exclude shareholders that are recorded both in Bankscope and Amadeus with a generic name (e.g. "Institutions", "Management", "Private shareholders") for which we cannot identify a specific individual or company. Nonetheless, we retain the company data and calculate the ultimate ownership for all remaining identifiable shareholders.

We believe that dropping shareholders with generic names does not bias the identification of the ultimate shareholder and, ultimately, our analysis. According to Bureau van Dijk Ownership Database Guidelines: "[...]categories such as 'Unnamed private shareholders, aggregated'; and 'Other unnamed shareholders, aggregated' are considered as unable to exert, as such, control over a company.[...]."7 Indeed, on average, the combined Bankscope and Amadeus ownership database that we construct identifies, by name, direct owners of about $82.4 \%$ of the firm's equity, which corresponds to 2.09

\footnotetext{
${ }^{5}$ Further, the Bureau van Dijk team has confirmed that banks are never actually removed from Bankscope even when banks stop releasing financial accounts. This ensures that the possibility of survivorship biases in the data is minimized. Nonetheless, the way we reassemble the panel dataset from each single DVD further addresses this potential concern.

${ }^{6}$ For France, Germany, Italy, Russia, Spain, Ukraine, and the UK, Amadeus includes all companies with revenues of at least $€ 15 \mathrm{~m}$, or total assets of at least $€ 30 \mathrm{~m}$, or at least 200 employees. For other countries, it includes all companies with operating revenues of at least $€ 10 \mathrm{~m}$, or total assets of at least $€ 20 \mathrm{~m}$, or at least 150 employees. The database excludes companies with operating revenues per employee or total assets per employee of less than $€ 1000$.

7 Bureau van Dijk Ownership Database Guidelines, p. 5.
} 
shareholders. The largest direct stake amounts to $69.29 \%$ on average suggesting that, in the aggregate, for those firms for which ownership data are available, the combined ownership database provides broad coverage. $^{8}$

As for the accounting side of the database, we winsorize all accounting variables at the bottom and top $1 \%$ of the distribution to reduce the effect of outliers. After combining the ownership and portfolio diversification with the accounting data, the final database comprises 4,768 bank-year observations corresponding to 1,184 unique banks and 3,010 shareholders across 36 European countries.

\subsection{Ultimate largest shareholders}

Once we have all direct shareholders, we proceed with the identification of the ultimate shareholders for each bank each year. That is, when we find that a bank is owned by another company (either financial or non-financial), we identify the owners of that company and so on until we cannot trace back any further. In a very simple pyramid structure, if shareholder A owns a fraction $x$ of equity in company B, which owns in turn a fraction $y$ of equity in bank $C$, shareholder A then is identified as the ultimate shareholder of bank C. Fig. 1 Panel A illustrates a stylized example of this "pyramid" structure. We trace back pyramids of any length without imposing any cut-off threshold.

As in previous studies (e.g. Claessens et al., 2000; Faccio and Lang, 2002), we calculate the Cash Flow Rights of each ultimate shareholder as the product between links along the chain; and the Control Rights as the weakest link along the chain. In the example above, the Cash Flow Rights of shareholder A in bank $C$ are equal to $C F_{A C}=x \times y$, while the Control Rights are equal to $C R_{A C}=\min [x, y]$.

Further, we account for the possibility that the ultimate shareholder controls a bank via a multitude of control chains. In the previous example, we supposed that shareholder A also holds a direct fraction $z$ of bank C. Fig. 1 Panel B illustrates a stylized example of this "multiple control chain" structure. Following Faccio and Lang (2002), Cash Flow Rights of shareholder A become equal to $C F_{A C}=(x \times y)+z$, and Control Rights become equal to $C R_{A C}=(\min [x, y])+z .^{9}$

After having traced all ultimate shareholders, for each company each year we define the Largest Ultimate Shareholder as the ultimate shareholder with the highest Control Rights. We then exclude banks where the State is the largest ultimate shareholder, as state-owned banks have different risk-taking incentives than non-state-owned banks (e.g. La Porta et al., 2002; Caprio et al., 2007; De Nicoló and Loukoianova, 2007). ${ }^{10}$ Finally, we exclude banks controlled through cross-holding as it is problematic to identify the ultimate shareholder within this complex ownership structure. We proceed then to construct our measures of portfolio diversification.

\subsection{Portfolio diversification variables}

Our first measure of portfolio diversification is the total number of equity positions that the Largest Ultimate Shareholder holds directly and indirectly across all companies included in the combined Bankscope and Amadeus ownership database each year (No. of Firms). As the distribution of No. of Firms is highly skewed, in our analysis we use the logarithmic transformation (Ln No. of Firms) to limit the impact of extreme values. This measure has been commonly used in previous studies (e.g. Barber and Odean, 2000; Campbell et al., 2001; Faccio et al., 2011; Goetzmann and Kumar, 2008; Karhunen and Keloharju, 2001; Statman, 1987) to reflect a well-documented stylized fact in literature that the higher the number of stocks held in a portfolio the greater the potential for a better portfolio diversification (e.g. Campbell et al., 2001; Merton, 1992). Note that to construct this variable we only require to have ownership information of each company regardless of the availability of accounting data. It has also the advantage that it does not require any information on the overall wealth of each investor and the returns of the stocks included in the portfolio.

\footnotetext{
8 In these calculations we still include ownership by State.

9 We find that about $2 \%$ of all bank-year observations in Bankscope are controlled through a "multiple control chain" structure.

${ }^{10}$ We use several key words to identify "State" shareholders, such as "State of", "City of", "Ministry" in different languages. We find that more than $11 \%$ of banks are State-owned. This mirrors the evidence reported in Survey I, II, and III by Barth et al. (2006 and 2008).
} 


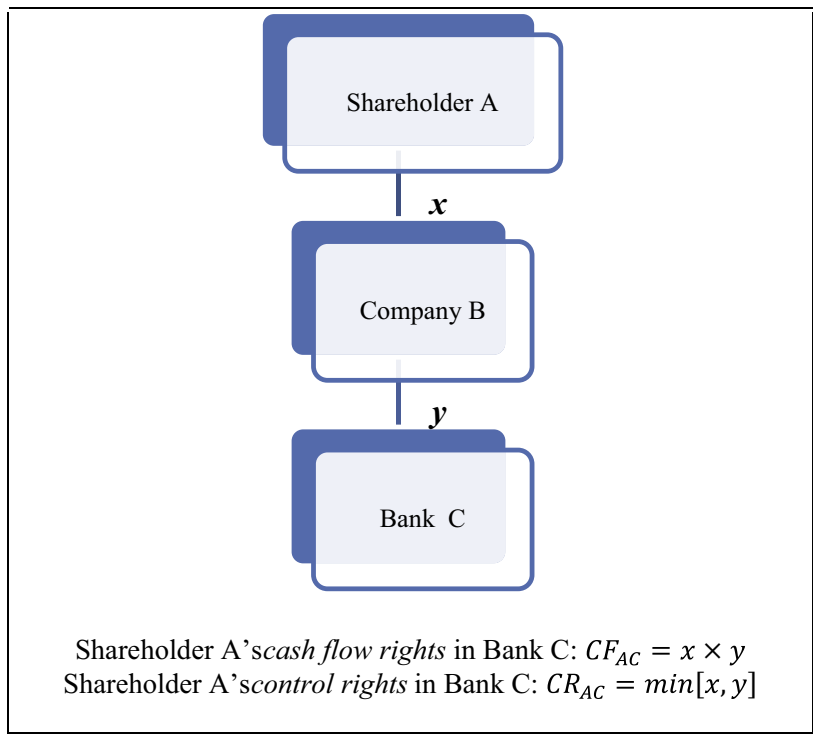

Fig. 1A. Stylized example of pyramid.

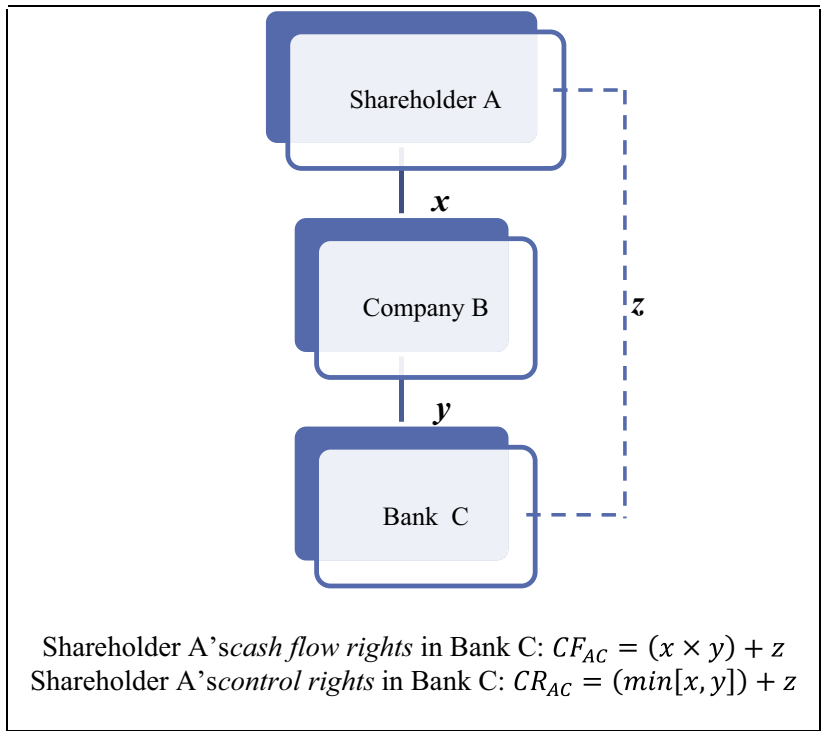

Fig. 1B. Stylized example of multiple control chain.

Nonetheless, it may be argued that this measure may overstate the true value of bank shareholders' portfolio diversification. For instance, one investor may hold most of her wealth in one company and diversify the rest in many other firms. Alternatively, she may invest in a multitude of companies that are all exposed to the same idiosyncratic risks. In both cases, although the high number of firms held in her portfolio, one could arguably doubt the degree of diversification of her wealth. 
We therefore use two alternative measures that possibly alleviate the shortcomings of the first one. Nonetheless, we acknowledge that each of these two measures come (unavoidably) with their own limitations too.

Similar to Bodnaruk et al. (2008), Demsetz and Lehn (1985), Faccio et al. (2011), and Goetzmann and Kumar (2008) we use the Herfindahl Index (HI) of ownership concentration for each bank largest ultimate shareholder as a measure of wealth concentration. We construct it as follows:

$$
H I_{A}=\sum_{c=1}^{N} F W_{A c}^{2}
$$

where

$$
F W_{A c}=\frac{B E_{C} \times C F_{A c}}{T W_{A}}
$$

and:

$$
T W_{A}=\sum_{c=1}^{N}\left(B E_{c} \times C F_{A c}\right)
$$

where $\left(B E_{c} \times C F_{A c}\right)$ represents the dollar value investment of shareholder $A$ in each company $c$ of her portfolio, and it is equal to the product between the book value of equity of company $c\left(B E_{c}\right)$ and the fraction of Cash Flow Rights of shareholder $A$ in that company $\left(C F_{A c}\right)$; $T W_{A}$ is the total portfolio value of shareholder $A$, which approximates the Total Equity Wealth of shareholder $A$, and it is equal to the sum of all investment made by shareholder $A$ in the companies included in her portfolio; $F W_{A C}$ represents the Fraction of Wealth of shareholder $A$ invested in company $c$, or in other words, the weight that company $c$ has in the shareholder $A$ 's portfolio. To compute this measure we require data on the book value of equity of the firms included in each shareholder's portfolio. ${ }^{11}$ This measure represents the divergence of the shareholder's portfolio from the market portfolio, under the assumption that the security weights of the well diversified market portfolio are close to zero. This is why $\mathrm{HI}$ is also often used as an alternative proxy for portfolio diversification. ${ }^{12}$

The value of $H I$ ranges from 0 to 1 , where values closer to 1 indicate a higher degree of wealth concentration (lower portfolio diversification). Therefore, to make the interpretation consistent across all proxies of portfolio diversification, in the analysis we use (1-HI) so that higher values of this variable indicate higher diversification.

The third proxy of portfolio diversification is -Correlation, which is the average correlation of the firm's industry stock returns with the shareholder's overall portfolio returns, multiplied by -1 , as in Bodnaruk et al. (2008) and Faccio et al. (2011). We use the industry returns as a proxy for the returns on a given stock in order to have a minimum number of observations so as to estimate this independent variable with relatively little noise. (This is particularly relevant when the firm in question is privately held.) The industry (weekly) return is defined as the average of (weekly) returns of all publicly traded European companies in each 4-digit SIC industry, with stock price data available in Datastream. For each investor, the portfolio returns are computed as the weighted average of returns on the individual stocks in her portfolio, where the weights used are the weights of each firm in the investor's portfolio, $F W_{A c}$, measured at the beginning of each year. The returns of the industry to which each stock belongs are used as a proxy for the returns of each stock in the investor's portfolio. This measure reflects higher diversification when the stocks included in the portfolio are from industries whose returns are not highly correlated with the rest of the investor's portfolio returns. Compared with

\footnotetext{
${ }^{11}$ For non-financial firms the book value of equity is equal to the sum of "Shareholders Capital Funds" and "Other Shareholder Funds" as available in Amadeus. For banks, it is equal to "Total Equity" as reported in Bankscope.

${ }^{12}$ Following Faccio et al. (2011), the divergence of a shareholder's portfolio from the market portfolio can be measured as $\sum_{c=1}^{N}\left(F W_{A c}-F W_{M k t c}\right)^{2}$, where $F W_{A c}$ is the fraction of wealth of shareholder $A$ in company $c$ or, in other words, it represents the weight of security $c$ in the portfolio of shareholder A; while $F W_{M k t c}$ is the weight of that security $c$ in the market portfolio (Mkt). As the number of stocks in the market portfolio increases, the weight of each security tends to zero, such that $\sum_{c=1}^{N}\left(F W_{A c}-F W_{M k t c}\right)^{2} \approx \sum_{c=1}^{N} F W_{A c}^{2}$, which corresponds to our HI measure.
} 
our first measure of diversification, -Correlation is likely to understate diversification because the returns of stocks from the same industry are perfectly positively correlated.

Despite the broad coverage of the combined Bankscope and Amadeus ownership database, we acknowledge that our proxies of portfolio diversification may have some limitations. For instance, they may be geographically limited, as equity holdings of non-financial firms outside Europe are not included in Amadeus. Nonetheless, there is extensive evidence in the literature suggesting that investors often prefer to hold equities in domestic firms and exhibit "geographically-biased" equity portfolios ("Home bias puzzle" as described by French and Poterba, 1991; Cooper and Kaplanis, 1994; and Coval and Moskowitz, 1999). More recent findings show that this trend is still very strong even in countries with developed capital markets (Sorensen et al., 2007). ${ }^{13}$ To test how strong this potential bias is, we use the direct ownership information of all non-financial companies across 200 countries included in the Orbis database for 2008 . With these data we reconstruct the equity holdings portfolios of our bank ultimate largest shareholders in that year and compare it with our (Bankscopeand Amadeus-based) measure of portfolio. The correlation between the two measures is $97 \%$ with a $p$ value of less than 0.01 , which suggests that the geographic limitation of our measure should not severely affect our estimations. Also, in the panel regression analysis we always include shareholder fixed effects that, at least partially, should control for shareholder investment preferences.

A further source of concern could be that investments in (very) small (non-)financial companies not included in the combined database are neglected. However, since they are small, it is likely that their impact on the value-based proxies of portfolio concentration, i.e. HI, is limited. Finally, we are not able to capture indirect equity investments e.g. through mutual funds. Nonetheless, in Section 5.2 we present robustness tests that show how this limitation is not likely to affect our main conclusions. ${ }^{14}$

\subsection{Risk-taking proxy}

Consistent with several previous studies on banking (e.g. Boyd et al., 1993; García-Marco and Robles-Fernández, 2008; Laeven and Levine, 2009), our main proxy for bank risk-taking is the (inverse) Roy's Z-score. The advantage of this measure is that it does not rely on market values, something which is crucial for us given that our sample mainly includes privately held banks. The idea behind the Z-score goes back to Roy (1952) and it relates to the "safety first" principle: an economic agent with uncertainty will optimize expected profits by choosing a level of assets and liabilities to minimize the probability of insolvency (that occurs when the value of assets is lower than the value of liabilities). Using the Bienaymé-Tchebycheff inequality, this has been translated into a measure of the distance to default defined as:

$$
P\left(\left|\pi-\varepsilon_{t}\right| \geqslant \pi-d\right)=P\left(\varepsilon_{t} \leqslant d\right) \leqslant \frac{\sigma^{2}}{(\pi-d)^{2}}
$$

where $\pi$ is the expected return of the assets; $\sigma$ is the standard deviation the returns of the assets; $\varepsilon_{t}$ is the random value of the return on the assets in period $t$, with mean equal to $\pi$, and standard deviation $\sigma ; d$ is the "disaster level" or the level of liabilities that would trigger the default. The Z-score is interpreted as the number of standard deviations away from the mean of returns necessary to reach the agent's default level. In other words, it measures the probability that the agent is solvent. Bank insolvency is then defined as the state in which its losses $(-\pi)$ are greater than the value of its equity ( $E$, defined as the default level). Thus, we can rewrite Roy's score as $P(-\pi \geqslant E)=P(\pi \leqslant-E)$. If we substitute $\pi$ with bank return on assets (ROA) and $E$ with the value of bank equity relative to total assets (Capital Asset Ratio, CAR), as in Laeven and Levine (2009), we obtain $P(\pi \leqslant-E) \equiv P(R O A \leqslant-C A R)$. The expression $-C A R$ is interpreted as the bank's leverage. So the bank's probability of default is defined as:

\footnotetext{
13 They calculate that at the end of 2003, $70 \%$ of the UK total equity portfolio was in domestic equity; similarly for Spain (86\%), France (72\%), Italy (69\%), and Germany (66\%).

${ }^{14}$ One further limitation is that we consider only investment in equity positions. Given the size of our sample, we are not able to retrieve information on investment in other assets such as bonds, real estate or cash.
} 


$$
P(R O A \leqslant-C A R) \leqslant\left(\frac{\sigma_{i, R O A}}{R O A_{i}+C A R_{i}}\right)^{2} \equiv \frac{1}{Z \text { score }_{i}}
$$

Inverse $Z$-score indicates that the probability of default depends on the relation between the bank's $i$ profitability $\left(R O A_{i}\right)$, the riskiness of its returns $\left(\sigma_{i, R O A}\right)$ and its existing level of capital reserves $\left(C A R_{i}\right)$. For simplicity we call this ratio $Z$-score throughout the paper. It represents the bank's exposure to operating losses that would reduce the buffer (capital reserves) against potential shocks to the returns (García-Marco and Robles-Fernández, 2008). This also measures the bank's risk-taking as riskier investment decisions increase the volatility of profits which in turn raises the probability of default.

In our panel regressions, we calculate each component of the $Z$-score $\left(\sigma_{i, R O A}, R O A\right.$ and CAR) over five consecutive year overlapping periods, that is, 2000-2004, 2001-2005, 2002-2006, 2003-2007 and 2004-2008. The volatility of ROA $\left(\sigma_{i, R O A}\right)$ is the standard deviation of the ratio of gross pre-tax profit to total assets for each bank over each overlapping panel. Gross pre-tax profit is defined as the sum of pre-tax profit and loan loss provisions. Similarly, we calculate the average of $R O A$ and average of $C A R$ (defined as the ratio of equity to total assets) for each bank. In the analysis we use the logarithm of the inverse of the Z-score ( $L n Z$-score) to smooth the effect of extreme values. For simplicity, we report all variable definitions in Table 1.

\section{Results: portfolio diversification and bank risk-taking}

\subsection{Univariate analysis}

Table 2 reports country-level descriptive statistics of our sample. The final sample includes 1,184 banks across 36 countries, and at least one bank in each country. The countries with the most bank observations in the sample are Italy, France, Germany, UK, Spain and the Russian Federation. Most banks are privately held (76\%). Privately held banks do play an important role in the economic system. For instance, over the decade 2001-2010, privately held banks in the Euro area provided about $71 \%$ of the total loans of commercial banks. Similarly, in the UK they contributed an average of $60 \%{ }^{15}$ It is therefore crucial to include privately held banks in our analysis to better understand the economic incentives that govern one of the most important players in the capital markets.

Table 3 shows descriptive statistics of the main variables included in our analysis at shareholder (Panel A) and bank level (Panels B and C). The average largest ultimate shareholder in our sample appears to be rather diversified, holding an equity portfolio of stocks from on average thirteen firms (median of two firms), in three different countries. Across the whole sample, 62\% of shareholders hold stocks from at least two firms in their portfolio (Diversified dummy), 23\% from at least ten companies, and $7 \%$ from more than 50 companies. On the other hand, the wealth diversification $(1-H I)$ of the average largest shareholder is equal to 0.20 . A (1-HI) value of 1 indicates perfect diversification. So despite holding a fairly diversified portfolio, a large portion of the average largest shareholder's wealth seems to be concentrated in one (or a few) company. In fact, almost half seems to be invested in the bank controlled by the average largest shareholder (Fraction of Wealth almost equal to 54\% in Panel B). Further, our third proxy of diversification, -Correlation, suggests that a significant fraction of the companies in the average largest shareholder portfolio belong to the same industry. A -Correlation value of 1 indicates perfect diversification.

These figures provide new insights into bank shareholder characteristics that complement previous evidence. Previous studies have shown that the average investor is only moderately diversified: Barber and Odean (2000) and Goetzmann and Kumar (2008) report that individual investors in the US hold an average of four different equity investments, while Faccio et al. (2011) show that shareholders of European non-financial companies hold equities in about four different firms. Further, Sullivan and Spong (2007) show in a limited sample of US state-chartered banks that between 1993 and 1994

\footnotetext{
${ }^{15}$ We use a number of sources to calculate these figures. First, from Bloomberg we collect data on total loans of all publicly traded commercial banks in the Euro area countries and the UK each year over the 2001-2010 period. Second, we gather data on total loans of all Euro area and the UK commercial banks from the European Central Bank Statistical Warehouse and the Bank of England, respectively.
} 
Table 1

Variable definitions and sources.

\begin{tabular}{|c|c|}
\hline \multicolumn{2}{|c|}{ Portfolio diversification } \\
\hline Ln No. of Firms & $\begin{array}{l}\text { Natural logarithm of the total number of firms owned directly or indirectly by each bank largest } \\
\text { shareholder. Sources: Bankscope, Amadeus }\end{array}$ \\
\hline \multirow[t]{3}{*}{$(1-H I)$} & $\begin{array}{l}\text { (1- the Herfindahl Index) where the Herfindahl Index measures the ownership concentration of } \\
\text { shareholders, calculated as the squared sum of each weighted investment in the shareholder's }\end{array}$ \\
\hline & portfolio, relative to the shareholder's total wealth, $H I_{A}=\sum_{c=1}^{N} F W_{A c}^{2}$ where $F W_{A c}=\frac{B E_{C} \times C F_{A c}}{T W_{A}}$ and \\
\hline & $\begin{array}{l}\text { represents the Fraction of Wealth; while }\left(B E_{c} \times C F_{A c}\right) \text { represents the dollar value investment of } \\
\text { shareholder } A \text { in each company } c \text { of her portfolio, and is equal to the product between the book } \\
\text { value of equity of company } c\left(B E_{c}\right) \text { and the fraction of Cash Flow Rights of shareholder } A \text { in that } \\
\text { company }\left(C F_{A c}\right) ; T W_{A} \text { is the total portfolio value of shareholder } A \text {, which approximates the Total } \\
\text { Equity Wealth of shareholder } A \text {, and it is equal to the sum of all investment made by shareholder } \\
A \text { in the companies included in her portfolio. Sources: Bankscope, Amadeus }\end{array}$ \\
\hline -Correlation & $\begin{array}{l}\text { Correlation of the stock returns of a firm's } 4 \text {-digit SIC industry with the shareholder's overall } \\
\text { portfolio returns, multiplied by }-1 \text {. Sources: Bankscope, Amadeus, Datastream }\end{array}$ \\
\hline Ln No. of Countries & $\begin{array}{l}\text { Natural logarithm of the total number of countries where the largest shareholder invests. } \\
\text { Sources: Bankscope, Amadeus }\end{array}$ \\
\hline Diversified dummy & $\begin{array}{l}\text { Dummy equal to one if the ultimate largest shareholder's portfolio holds stocks from at least } \\
\text { two companies, zero otherwise. Sources: Bankscope, Amadeus }\end{array}$ \\
\hline Fraction of wealth & $\begin{array}{l}\text { Fraction of wealth is defined by } F W_{A c}=\frac{B E_{C} \times C F_{A c}}{T W_{A}} \text { and represents the weighted investment in } \\
\text { company } c \text { with respect to shareholder } A \text { 's portfolio. Sources: Bankscope, Amadeus }\end{array}$ \\
\hline Cash flow rights & $\begin{array}{l}\text { Cash flow rights held by the ultimate largest shareholder. If shareholder A owns a fraction } \mathrm{x} \text { of } \\
\text { company B, which owns in turn a fraction y of bank C, shareholder A then is identified as the } \\
\text { ultimate shareholder of bank } \mathrm{C} \text {. Cash Flow Rights of each ultimate shareholder are the product } \\
\text { between links along the chain, } C F_{A C}=x \times y \text {. Sources: Bankscope, Amadeus }\end{array}$ \\
\hline Control rights & $\begin{array}{l}\text { Control (voting) rights held by the ultimate largest shareholder. In the same example above, } \\
\text { Control Rights are the weakest link along the chain, } V R_{A C}=\min [x, y] \text {. Sources: Bankscope, } \\
\text { Amadeus }\end{array}$ \\
\hline
\end{tabular}

Risk-Taking

Z-score

Volatility of $R O A\left(\sigma_{i, R O A}\right)$

Survival

Other controls

Managerial ownership

Size
CAR
Net interest marginal
$\quad$ revenue
Interest activity
Loan loss provisions

Private dummy
Ratio of the volatility of $R O A$ ( $\left.\sigma_{i, R O A}\right)$ to the sum of average return on asset ( $\operatorname{avgROA}$ ) and average capital asset ratio (avgCAR). ROA is defined as the ratio of the gross pre-tax profit (including loan loss provisions) to total assets. The volatility of ROA is the standard deviation of ROA; avgROA is the average of $R O A$; avgCAR is the average ratio of equity to total assets. Each component of the $Z$-score is calculated over five consecutive year overlapping periods, that is, 2000-2004, 2001-2005, 2002-2006, 2003-2007 and 2004-2008. Source: Bankscope

Standard deviation of $R O A$ calculated over five consecutive year overlapping periods, that is, 2000-2004, 2001-2005, 2002-2006, 2003-2007 and 2004-2008. ROA is defined as the ratio of the gross pre-tax profit (including loan loss provisions) to total assets. Source: Bankscope Dummy equal to 1 if a bank, entering our sample between 1999 and 2004, is still in the sample for at least five years, and zero otherwise. Source: Bankscope

Total equity holdings for all managers in each bank each year. Bankscope provides the full names and positions of all directors in the board for each bank each year. To retrieve their ownership information, we search for each director's name in the complete list of direct shareholders of each bank each year. We then sum all the equity holdings for all manager-shareholder matches. When we cannot find a proper match, we use the ownership data of those shareholders recorded in Bankscope with a generic name that directly relates to a director ownership position (e.g. "Management", "Executives", "Board members"). We use this information as the managerial ownership of that bank that year. We replace Managerial Ownership with a zero when we cannot retrieve this information any further. Sources: Bankscope Natural logarithm of total assets. Source: Bankscope

Ratio of equity to total assets. Source: Bankscope

Ratio of the difference between interest income and interest expenses to the interest income. Source: Bankscope

Ratio of interest income to total operating income. Source: Bankscope

Ratio of Loan Loss Provision (LLP) reported in banks' income statements to Interest Income.

Source: Bankscope

Dummy equal to one if the bank is privately held, zero otherwise. Source: Bankscope 
Table 1 (continued)

\begin{tabular}{|c|c|}
\hline Portfolio diversification & \\
\hline Wedge & $\begin{array}{l}\text { Difference between Control Rights and Cash Flow Rights of each largest shareholder in each bank. } \\
\text { Sources: Bankscope. Amadeus }\end{array}$ \\
\hline Wedge dummy & $\begin{array}{l}\text { Dummy equal to } 1 \text { if there is a positive difference between Control Rights and Cash Flow Rights, } \\
\text { zero otherwise. Sources: Bankscope, Amadeus }\end{array}$ \\
\hline Foreign & $\begin{array}{l}\text { Dummy equal to } 1 \text { if the country of origin of the largest shareholder is different from the } \\
\text { country where the bank she controls is headquartered, zero otherwise. Sources: Bankscope, } \\
\text { Amadeus, several internet-based sources }\end{array}$ \\
\hline Financial shareholder & $\begin{array}{l}\text { Dummy equal to } 1 \text { if the ultimate largest shareholder is either classified as an Institutional } \\
\text { Investor, Bank or Insurance company, and zero otherwise. Sources: Bankscope, Amadeus, several } \\
\text { internet-based sources }\end{array}$ \\
\hline Institutional Investor & $\begin{array}{l}\text { Dummy equal to } 1 \text { if the ultimate largest shareholder is classified as Institutional Investor, and } \\
\text { zero otherwise. Sources: Bankscope, Amadeus, several internet-based sources }\end{array}$ \\
\hline Bank & $\begin{array}{l}\text { Dummy equal to } 1 \text { if the ultimate largest shareholder is classified as Bank, and zero otherwise. } \\
\text { Sources: Bankscope, Amadeus, several internet-based sources }\end{array}$ \\
\hline Insurance & $\begin{array}{l}\text { Dummy equal to } 1 \text { if the ultimate largest shareholder is classified as Insurance company, and } \\
\text { zero otherwise. Sources: Bankscope, Amadeus, several internet-based sources }\end{array}$ \\
\hline Non-financial company & $\begin{array}{l}\text { Dummy equal to } 1 \text { if the ultimate largest shareholder is classified as non-financial company, } \\
\text { and zero otherwise. Sources: Bankscope, Amadeus, several internet-based sources }\end{array}$ \\
\hline Bank type & Dummy equal to one if a bank is a commercial bank, and zero otherwise. Source: Bankscope \\
\hline Capital stringency index & $\begin{array}{l}\text { The Capital Stringency Index measures the regulatory approach to assessing the degree of } \\
\text { capital at risk in a bank. This Index is based on the following questions: (1) Is the minimum } \\
\text { capital asset ratio requirement risk weighted in line with the Basel guidelines? (2) Does the } \\
\text { minimum ratio vary as a function of market risk? (3) Are market values of loan losses not } \\
\text { realized in accounting books deducted from capital? (4) Are unrealized losses in securities } \\
\text { portfolios deducted? (5) Are unrealized foreign exchange losses deducted? (6) What fraction of } \\
\text { revaluation gains is allowed as part of capital? (7) Are the sources of funds to be used as capital } \\
\text { verified by the regulatory or supervisory authorities? (8) Can the initial disbursement or } \\
\text { subsequent injections of capital be made with assets other than cash or government securities? } \\
\text { (9) Can initial disbursement of capital be made with borrowed funds? Source: Barth et al. (2006) }\end{array}$ \\
\hline Restrict index & $\begin{array}{l}\text { The Restrict Index measures the regulatory barriers for banks to undertake non-lending } \\
\text { activities. It measures the extent to which banks are allowed by the regulator to engage in } \\
\text { securities market activities (e.g. underwriting, brokering, dealing, and all aspects of the mutual } \\
\text { fund industry), insurance activities (e.g. insurance underwriting and selling), real estate } \\
\text { activities (e.g. real estate investment, development, and management), and the ownership of } \\
\text { non-financial firms. Source: Barth et al. (2006) }\end{array}$ \\
\hline Creditor rights index & The Creditor Rights Index is from La Porta et al. (1998) \\
\hline $\begin{array}{l}\text { Depth of credit } \\
\text { information }\end{array}$ & $\begin{array}{l}\text { This is a measure of the availability of credit information from either a public registry or a } \\
\text { private bureau to facilitate lending decisions. It ranges from } 0 \text { to } 6 \text {, with higher values indicating } \\
\text { more credit information available. Source: Djankov et al. (2007) }\end{array}$ \\
\hline $\begin{array}{l}\text { Financial statement } \\
\text { transparency }\end{array}$ & $\begin{array}{l}\text { This measures the transparency of bank financial statement practices. Higher values indicate } \\
\text { more transparency. Source: Barth et al. (2006) }\end{array}$ \\
\hline
\end{tabular}

average owner-managers invested $86 \%$ of their personal wealth in the bank they managed. Overall, our evidence seems to indicate that, on average, bank shareholders are more diversified than individuals and non-financial firms' shareholders, although a large fraction of their wealth seems to be concentrated in one company (or in one industry).

In addition, descriptive statistics in Panel B show that the average bank largest shareholder holds about 39\% of Cash Flow Rights (CF) and more than 40\% of Control Rights (CR). These figures are higher than those provided in earlier studies on banking, possibly due to the inclusion in our sample of privately held banks. ${ }^{16}$ They suggest that the largest shareholder in our sample is indeed a powerful investor able to take decisions within the owned bank. Interestingly, the correlation between ownership

\footnotetext{
${ }^{16}$ Based on Faccio and Lang (2002) data, in Western European countries the average cash flow rights (control rights) of the largest ultimate shareholder of financial companies at 10\% cut-off are 31\% (35\%); while Laeven and Levine (2009) report 20.5\% (29.6\%). 
Table 2

Country sample distribution.

\begin{tabular}{|c|c|c|c|c|}
\hline \multirow[t]{2}{*}{ Country } & \multirow[t]{2}{*}{ Total Obs } & \multicolumn{2}{|c|}{ Total observations \% } & \multirow[t]{2}{*}{ Total Assets (Billions USD) } \\
\hline & & Public & Private & \\
\hline Albania & 13 & $0.00 \%$ & $100.00 \%$ & 2.37 \\
\hline Austria & 64 & $20.31 \%$ & $79.69 \%$ & 465.02 \\
\hline Belgium & 141 & $9.93 \%$ & $90.07 \%$ & 2046.38 \\
\hline Bosnia-Herzegovina & 38 & $0.00 \%$ & $100.00 \%$ & 3.35 \\
\hline Bulgaria & 86 & $11.63 \%$ & $88.37 \%$ & 12.42 \\
\hline Croatia & 98 & $39.80 \%$ & $60.20 \%$ & 42.22 \\
\hline Cyprus & 25 & $48.00 \%$ & $52.00 \%$ & 45.19 \\
\hline Czech Republic & 63 & $23.81 \%$ & $76.19 \%$ & 80.32 \\
\hline Denmark & 163 & $63.80 \%$ & $36.20 \%$ & 750.43 \\
\hline Estonia & 17 & $41.18 \%$ & $58.82 \%$ & 12.31 \\
\hline Finland & 33 & $42.42 \%$ & $57.58 \%$ & 185.71 \\
\hline France & 773 & $14.49 \%$ & $85.51 \%$ & 6893.56 \\
\hline Germany & 661 & $11.95 \%$ & $88.05 \%$ & 5711.17 \\
\hline Greece & 41 & $87.80 \%$ & $12.20 \%$ & 135.49 \\
\hline Hungary & 31 & $29.03 \%$ & $70.97 \%$ & 24.37 \\
\hline Iceland & 29 & $34.48 \%$ & $65.52 \%$ & 71.61 \\
\hline Ireland & 54 & $22.22 \%$ & $77.78 \%$ & 422.64 \\
\hline Italy & 845 & $21.78 \%$ & $78.22 \%$ & 3440.14 \\
\hline Latvia & 55 & $3.64 \%$ & $96.36 \%$ & 10.78 \\
\hline Lithuania & 38 & $57.89 \%$ & $42.11 \%$ & 13.03 \\
\hline Malta & 18 & $72.22 \%$ & $27.78 \%$ & 6.37 \\
\hline Republic of Moldava & 31 & $29.03 \%$ & $70.97 \%$ & 0.71 \\
\hline Netherlands & 71 & $12.68 \%$ & $87.32 \%$ & 1073.19 \\
\hline Norway & 159 & $74.21 \%$ & $25.79 \%$ & 289.08 \\
\hline Poland & 112 & $42.86 \%$ & $57.14 \%$ & 76.58 \\
\hline Portugal & 115 & $33.91 \%$ & $66.09 \%$ & 404.65 \\
\hline Romania & 77 & $11.69 \%$ & $88.31 \%$ & 29.06 \\
\hline Russian Federation & 193 & $8.29 \%$ & $91.71 \%$ & 116.90 \\
\hline Serbia & 21 & $0.00 \%$ & $100.00 \%$ & 3.63 \\
\hline Slovakia & 62 & $29.03 \%$ & $70.97 \%$ & 28.18 \\
\hline Slovenia & 70 & $24.29 \%$ & $75.71 \%$ & 42.70 \\
\hline Spain & 202 & $35.15 \%$ & $64.85 \%$ & 2048.14 \\
\hline Sweden & 73 & $50.68 \%$ & $49.32 \%$ & 1190.51 \\
\hline Ukraine & 60 & $3.33 \%$ & $96.67 \%$ & 13.81 \\
\hline United Kingdom & 233 & $21.89 \%$ & $78.11 \%$ & 5023.40 \\
\hline Yugoslavia & 3 & $0.00 \%$ & $100.00 \%$ & 1.00 \\
\hline Total/average & 4768 & $24 \%$ & $76 \%$ & $30,716.41$ \\
\hline
\end{tabular}

This table reports the total number of European bank-year observations included in our sample. Values of Total Assets are expressed in billions of USD, inflation-adjusted using 2005 prices. Total Assets is calculated as the average over the sample period of the sum of total assets of all banks included in our sample in each country each year.

(Cash Flow Rights) and diversification (No. of Firms) across all bank-year observations is only -0.2 , which implies that in our sample we may have shareholders with relatively diversified portfolios that hold a large fraction of ownership in a single bank, and vice versa. When we isolate diversified largest shareholders (i.e. those with at least two companies in their portfolio) from the rest of the sample (Panel B), we still find that their average ownership is in line with that of undiversified shareholders (more than 37\% of Cash Flow Rights and almost 40\% of Control Rights). This is in line with Faccio et al. (2011), who caution researchers about using ownership concentration as a perfect proxy for portfolio diversification.

Finally, in Panel C we observe large heterogeneity in the main risk-taking measure. Figures show that $Z$-score varies from 0.003 (highly stable banks) to 0.326 (very insolvent banks). An average Z-score of 0.061 means that a bank's profits would have to decrease about 37 times their standard deviation before breaching the bank's default level. Thus, the higher the Z-score, the lower the (inverse) Z-score we use in our models and the less risky the bank. These figures are comparable to those reported in earlier studies (e.g. García-Marco and Robles-Fernández, 2008; Laeven and Levine, 2009). 
Table 3

Descriptive statistics.

\begin{tabular}{|c|c|c|c|c|c|c|}
\hline Variable & Mean & Std. Dev. & Median & Interquartile range & Min & Max \\
\hline \multicolumn{7}{|c|}{ Panel A. Shareholder-level data: shareholders' characteristics } \\
\hline No. of firms & 13.75 & 32.80 & 2.00 & 8.00 & 1.00 & 262.00 \\
\hline Ln No. of Firms & 1.30 & 1.44 & 0.69 & 2.20 & 0.000 & 5.57 \\
\hline$(1-\mathrm{HI})$ & 0.20 & 0.27 & 0.00 & 0.42 & 0.00 & 0.97 \\
\hline -Correlation & -0.90 & 0.19 & -1.00 & 0.11 & -1.00 & 0.05 \\
\hline No. of countries & 3.45 & 6.31 & 1.00 & 1.00 & 1.00 & 41.00 \\
\hline Ln No of countries & 0.57 & 0.94 & 0.00 & 0.69 & 0.00 & 3.71 \\
\hline Diversified dummy & 0.62 & 0.49 & 1.00 & 1.00 & 0.00 & 1.00 \\
\hline \multicolumn{7}{|c|}{ No. of shareholder observations 3,010} \\
\hline \multicolumn{7}{|c|}{ Panel B. Bank-level data: shareholders' characteristics } \\
\hline \multicolumn{7}{|l|}{ All shareholders } \\
\hline Cash flow rights & 38.64 & 36.16 & 25.00 & 62.72 & 0.00 & 100.00 \\
\hline Control rights & 40.10 & 35.59 & 27.68 & 61.59 & 0.01 & 100.00 \\
\hline Fraction of wealth & 0.54 & 0.45 & 0.60 & 0.98 & 0.00 & 1.00 \\
\hline Ln No. of firms & 1.94 & 1.69 & 1.61 & 3.38 & 0.00 & 5.57 \\
\hline$(1-\mathrm{HI})$ & 0.30 & 0.30 & 0.23 & 0.56 & 0.00 & 0.97 \\
\hline -Correlation & -0.87 & 0.21 & -1.00 & 0.27 & -1.00 & 0.05 \\
\hline Ln No of countries & 0.94 & 1.16 & 0.00 & 1.79 & 0.00 & 3.71 \\
\hline \multicolumn{7}{|c|}{ Shareholders with at least two firms in the portfolio } \\
\hline Cash flow rights & 37.46 & 36.78 & 21.33 & 63.83 & 0.00 & 100.00 \\
\hline Control rights & 39.45 & 36.06 & 25.01 & 62.92 & 0.01 & 100.00 \\
\hline Fraction of wealth & 0.41 & 0.43 & 0.18 & 0.97 & 0.00 & 1.00 \\
\hline \multicolumn{7}{|c|}{ Panel C. Bank-level data: banks' characteristics } \\
\hline Z-score & 0.061 & 0.062 & 0.041 & 0.048 & 0.003 & 0.326 \\
\hline Ln Z-score & -2.19 & 0.89 & -2.20 & 1.11 & -4.78 & -0.12 \\
\hline Ln Vol of ROA & -5.11 & 1.00 & -5.17 & 1.36 & -10.11 & -2.47 \\
\hline Managerial ownership & 0.14 & 2.12 & 0.00 & 0.00 & 0.00 & 59.53 \\
\hline Size & 14.29 & 2.11 & 14.10 & 2.72 & 7.87 & 20.82 \\
\hline CAR & 0.11 & 0.10 & 0.08 & 0.07 & 0.01 & 0.71 \\
\hline Net interest marginal revenue & 0.44 & 0.23 & 0.45 & 0.31 & -0.39 & 1.00 \\
\hline Interest activity & 2.10 & 2.36 & 1.36 & 1.08 & 0.00 & 13.45 \\
\hline Loan loss provisions & 0.07 & 0.08 & 0.05 & 0.09 & -0.03 & 0.35 \\
\hline Private dummy & 0.76 & 0.43 & 1.00 & 0.00 & 0.00 & 1.00 \\
\hline \multicolumn{7}{|c|}{ No. of banks observations 4,768} \\
\hline
\end{tabular}

This table reports summary statistics at shareholder- (Panel A), and bank-level (Panels B and C), of the main dependent and independent variables. Panel A includes statistics of portfolio diversification at shareholder-level. Panel B reports ownership as well as portfolio characteristics of shareholders at bank-level. Panel C reports all other banks' characteristics at bank-level. Please refer to Table 1 for the definitions of all variables.

\subsection{Multivariate analysis}

It is well known in literature that optimal financial decisions of investors are derived from individual and exogenously specified preference functions (Merton, 1992). In our analysis we are able to control for two main shareholder features, namely, the degree of diversification of equity portfolio and the ownership held in a specific bank. However, preferences may still differ across shareholders with similar observed characteristics, due to other traits that are not observed (e.g. age, total non-equity wealth) or to features that are unobservable (e.g. particular forms of the utility function). Omitting such variables may render all estimated coefficients in our regressions biased and inconsistent (Wooldridge, 2002). Further, it may also be that a shareholder might decide to invest in a bank with a risk profile that suits the shareholder's preferences to risk. In such a case, we would still observe a positive relation between portfolio diversification and bank risk-taking. However, this self-selection problem would bias the interpretation of our results since the causality would run from bank risk-taking to portfolio diversification and not the other way round.

Therefore, we exploit the panel dimension of our database and use panel data analysis that allows us to include shareholder fixed effects. The inclusion of shareholder fixed effects has two main 
advantages: (1) it controls for the potential omitted variable bias due to shareholder risk-taking incentives not captured by portfolio diversification; and (2) it addresses the potential for shareholders selecting banks with risk traits that suit their preference as opposed to shareholders shaping the risk profile of the bank they own. This is a unique and substantial improvement we have over most previous studies in banking that, due to data limitations, were able to exploit only the cross-sectional heterogeneity of shareholder characteristics (e.g. Gorton and Rosen, 1995; Laeven and Levine, 2009; Sullivan and Spong, 2007).

We estimate the following model:

$$
\begin{aligned}
(Z \text { Score })_{i, t, t+4)}= & \alpha+\beta \text { (Portfolio Diversification })_{i, t-1}+\sum_{j=1}^{J} \gamma_{j} X_{i j, t-1}+\text { Shareholder FE } \\
& + \text { Country FE } \times \text { Year FE }+u_{i, t-1}
\end{aligned}
$$

where we calculate each component of the Z-score ( $\sigma_{i, R O A}, R O A$ and $C A R$ ) over five consecutive year overlapping periods, that is, 2000-2004, 2001-2005, 2002-2006, 2003-2007 and 2004-2008. (Portfolio Diversification) $)_{i, t-1}$ represents either of the three measures of portfolio diversification of the largest shareholder in each bank at the beginning of each overlapping period. $X_{i j, t-1}$ is a vector of $j$ control variables for each bank $i$ taken at the beginning of each overlapping period. It includes: (1) Cash Flow Rights of the ultimate largest shareholder; (2) Managerial Ownership, measured as the fraction of shares held by all managers in each bank each year to control for potential agency conflicts between shareholders and managers (e.g. Saunders et al., 1990): ${ }^{17}$ (3) Size, measured as the natural logarithm of total assets, which is also proxy for a bank's ability to diversify its risks (e.g. Boyd and Runkle, 1993); (4) bank leverage, defined as the ratio of equity to total assets (CAR); (5) Net Interest Marginal Revenue, defined as the difference between interest income and interest expenses divided by interest income, which is a proxy of the profit margin (franchise value) of the bank (Hellmann et al., 2000; Keeley, 1990); (6) Interest Activity, measured as the ratio of interest income to total operating income, which should capture the degree of interest-generating banking activities relative to nontraditional banking activities (e.g. trading fees, non-deposits funding), and therefore, the level of specialisation of each bank; ${ }^{18}$ (7) Loan Loss Provisions, defined as the ratio of loan loss provisions to interest income, which is a proxy for credit quality and monitoring costs (Allen et al., 2011; Allen and Gale, 2004; Boyd and De Nicoló, 2005); (8) Private dummy, equal to one if a bank is privately held and zero otherwise, which should capture differences in risk-taking preferences between privately held and publicly traded banks (Barry et al., 2011). Besides shareholder fixed effects (Shareholder FE), we include Country $\times$ Year fixed effects to control for shocks that occurred to individual countries over time. Standard errors are robust to heteroskedasticity.

Table 4 reports the panel data estimates. The evidence is robust across all proxies of portfolio diversification: after controlling for potential omitted variable bias and self-selection problem, our findings suggest that a change in portfolio diversification effects a significant change in bank risktaking behaviour. In particular, the more diversified shareholders of a bank are, the more the solvency level of the bank seems to deteriorate. Further, this relation is not only statistically significant ( $p$-values $<0.05$ on average), but also economically sizeable. For instance, a standard deviation increase in Ln No. of Firms is likely to increase the insolvency ratio of the average bank by $3.4 \%$. This effect is remarkable if compared with the average impact of the other control variables in the same model, 3.8\%.

Most control variables have the expected sign. Net Interest Marginal Revenue is negatively associated with risk-taking, consistent with the idea that banks in very concentrated markets increase

\footnotetext{
${ }^{17}$ Bankscope provides the full names and positions of all directors on the board for each bank each year. To retrieve their ownership information, we search for each director's name in the complete list of direct shareholders of each bank each year. We then sum all the equity holdings for all manager-shareholder matches. When we cannot find a proper match, we use the ownership data of those shareholders recorded in Bankscope with a generic name that directly relates to a director ownership position (e.g. "Management", "Executives", "Board members"). We use this information as the Managerial Ownership of that bank that year. We replace Managerial Ownership with a zero when we cannot retrieve this information any further.

18 Banks engaging in non-traditional activities often tend to take on more risks (Demirgüç-Kunt and Huizinga, 2010). We therefore expect a negative relation between bank risk-taking and Interest Activity.
} 
Table 4

Panel data regressions.

\begin{tabular}{llll}
\hline & Ln no. of Firms & $(1-\mathrm{HI})$ & - Correlation \\
\hline Portfolio diversification & $0.0446^{* *}$ & $0.1588^{*}$ & $0.2715^{* *}$ \\
& {$[0.0113]$} & {$[0.0696]$} & {$[0.0475]$} \\
Cash flow rights & $\mathbf{3 . 4 3 \%}$ & $\mathbf{2 . 1 8 \%}$ & $\mathbf{2 . 5 9 \%}$ \\
& 0.0009 & 0.0005 & 0.0007 \\
Managerial ownership & {$[0.2596]$} & {$[0.5179]$} & {$[0.3609]$} \\
& 0.001 & 0.0014 & 0.0012 \\
Size & {$[0.9016]$} & {$[0.8571]$} & {$[0.8732]$} \\
& $-0.0304^{*}$ & -0.0271 & -0.0287 \\
CAR & {$[0.0834]$} & {$[0.1214]$} & {$[0.1005]$} \\
& $-0.6807^{* *}$ & $-0.6676^{* *}$ & $-0.6694^{* *}$ \\
Net interest marginal revenue & {$[0.0242]$} & {$[0.0273]$} & {$[0.0266]$} \\
Interest activity & $-0.8222^{* * *}$ & $-0.8209^{* * *}$ & $-0.8189^{* * *}$ \\
Loan loss provision & {$[0.0000]$} & {$[0.0000]$} & {$[0.0000]$} \\
Private dummy & $-0.0245^{* *}$ & $-0.0256^{*}$ & $-0.0248^{*}$ \\
Intercept & {$[0.0770]$} & {$[0.0663]$} & {$[0.0741]$} \\
Shareholder fixed effects & $0.6396^{*}$ & $0.6437^{*}$ & $0.6434^{*}$ \\
Country $\times$ Year fixed effects & {$[0.0731]$} & {$[0.0711]$} & {$[0.0710]$} \\
Adjusted $R$-squared & -0.0051 & -0.0107 & -0.001 \\
No. of observations & {$[0.9419]$} & {$[0.8774]$} & {$[0.9888]$} \\
\hline
\end{tabular}

This table reports panel data results where the dependent variable is the $L n Z$-score. Z-score is the ratio of volatility of ROA ( $\sigma_{i, R O A}$ ) to the sum of average return on assets $(\operatorname{avgROA})$ and average capital asset ratio (avgCAR). Each component of the Z-score is calculated over five consecutive year overlapping periods, that is, 2000-2004, 2001-2005, 2002-2006, 2003-2007 and $2004-$ 2008. All independent variables are taken at the beginning of each overlapping period. Please refer to Table 1 for the definitions of all variables. All regressions include Shareholder, and Country $\times$ Year fixed effects, and standard errors are correct for heteroskedasticity. The economic impact of each portfolio diversification proxy is reported below the corresponding $p$-value in bold. The economic impact is calculated as the percentage change of the average bank risk-taking in response to a standard deviation increase of the portfolio diversification variable. P-values are reported in brackets.

${ }^{*}$ Report the statistical significance at the $10 \%$ level.

*** Report the statistical significance at the $5 \%$ level.

*** Report the statistical significance at the $1 \%$ level.

their profitability up to the point of mitigating the risk-taking incentives of their shareholders (Hellmann et al., 2000; Keeley, 1990). Loans Loss Provisions and Interest Activity relate bank risk-taking to the banks' activities. In particular, Loans Loss Provisions is positively related to bank risk-taking, as higher (lower) monitoring costs (credit quality) increase the risk of lending. Interest Activity is inversely related to risk-taking, since those banks with a higher proportion of traditional interest-earning banking activities (i.e. interest deposits, mortgage lending) are able to implement more conservative portfolio choices (Demirgüç-Kunt and Huizinga, 2010).

Interestingly, the ownership of the largest shareholder (Cash Flow Rights), although showing the same sign of portfolio diversification, is not significant in any model and its impact is substantially lower than all portfolio diversification measures. This is further evidence that portfolio diversification does indeed enhance our understanding of risk-taking decisions in banks.

\subsection{Further endogeneity issues}

Results in the baseline analysis already control for potential endogeneity issues, i.e. omitted variable bias and self selection. Nonetheless, we undertake a number of steps to further minimize these concerns. 


\subsubsection{Self-selection}

To further address the question of whether largest shareholders affect bank risk-taking rather than simply select a bank with a risk profile that suits their risk preferences, we exploit the differences in the institutional settings regulating the ownership of banks across countries. Our starting point is the information on bank regulations collected by Barth et al. (2006, 2008, and 2013) in two consecutive surveys (Survey I in 1998/1999 and Survey II in 2003). In particular, we focus on two questions related to the regulatory restrictiveness of ownership of banks by both non-financial and non-bank financial firms, as these are likely to directly affect the portfolio diversification of bank largest shareholders: (1) the extent to which non-financial firms may own and control banks (question 2.3); and (2) the extent to which non-bank financial firms may own and control banks (question 2.5.1). The possible answers are: (1) unrestricted; meaning a non-financial (non-bank financial) firm may own 100 percent of the equity in a bank; (2) permitted; meaning unrestricted with prior authorization or approval; (3) restricted; meaning that limits are placed on ownership, such as a maximum percentage of a bank's capital or shares; and (4) prohibited; meaning that equity investment in a bank is not allowed. Following Barth et al. (2006, 2008, and 2013), we code each answer with progressive numbers from 1 to 4 , where higher values indicate higher restrictiveness. We then construct an index of restrictiveness of ownership of banks by summing the two answers for each country and survey (Restrictiveness Index). Since our sample does not include countries where the equity investment in a bank is prohibited, our restrictiveness index goes from 2 to 6 . We then perform two different tests.

First, we exploit the cross-sectional heterogeneity in the regulatory restrictiveness of ownership of banks as reported at the end of 2002 in Survey II by comparing the portfolio diversification and risktaking of banks across two sub-samples of countries with less restrictive and very restrictive regulations on ownership of banks. Countries with less (more) restrictive regulation are those with Restrictiveness Index below 3 (above 5). ${ }^{19}$ We employ a propensity score matching procedure (Rosenbaum and Rubin, 1983) to identify a control sample of banks headquartered in countries with very stringent regulation and that exhibit no observable differences in characteristics relative to the banks that are headquartered in countries with less restrictive regulation. We then compare the largest shareholders portfolio diversification and the risk-taking between the two groups. As the counterfactuals are restricted to a set of peers that is virtually identical based on observable characteristics, banks headquartered in less restrictive countries are expected to have largest shareholders with similar portfolio diversification and to make the same risk-taking choices as banks headquartered in very stringent countries. To implement this methodology, we calculate the probability (i.e. the propensity score) that a bank with given characteristics is headquartered in a less restrictive country. This probability is calculated using all bank characteristics that we included in the previous regression analyses except portfolio diversification. To ensure that the two groups of banks are sufficiently similar, we require that the maximum difference between the propensity score of the bank in a less restrictive country and that of its matching peer does not exceed $0.1 \%$ in absolute value. The $p$-value of the difference in mean propensity scores is 0.986 confirming that the two samples are statistically indistinguishable.

Table 5 shows that there is a significant difference in portfolio diversification. Indeed, less restrictive regulation on the ownership of banks seems to make investors more able/prone to acquire equity stakes in banks and so improve the diversification of their portfolio. Difference in portfolio diversification between the two groups is statistically significant, with a $p$-value $<0.001$. Further, we observe that banks in countries that allow investors to diversify more by holding banks' equity seem to take riskier choices. Difference in $Z$-score across the two groups is significant with a $p$-value of about 0.07 .

As an alternative test, we exploit the change in the regulatory restrictiveness of ownership of banks between Survey I and Survey II as an event that changes the portfolios of (at least some) investors. In particular, we focus on changes that make the regulations on ownership of banks more stringent over time since these are the most frequent events in our sample. We identify 18 instances where our Restrictiveness Index increases across the two surveys. ${ }^{20}$ According to Barth et al. (2008), many of the

\footnotetext{
19 Based on Survey II, at the end of 2002 Cyprus, Italy, Norway, and Ukraine were countries with very stringent regulations; while France, Greece, France, Switzerland, Poland, Island, and the UK were those with less restrictive regulations.

${ }^{20}$ Countries affected by these changes are: Albania, Austria, Bulgaria, Croatia, Estonia, Finland, France, Germany, Iceland, Ireland, Italy, Netherlands, Poland, Portugal, Romania, Russian Federation, Spain, and Sweden.
} 
Table 5

Propensity score matching estimations.

\begin{tabular}{cccccc}
\hline & $\begin{array}{l}\text { No. of } \\
\text { observations }\end{array}$ & Mean & $\begin{array}{l}\Delta \text { Mean (more restrictive }- \\
\text { less restrictive) }\end{array}$ & $\begin{array}{l}p \text {-Value } \\
\text { of diff. }\end{array}$ & $\begin{array}{l}p \text {-Value of diff. between } \\
\text { propensity scores }\end{array}$ \\
\hline $\begin{array}{c}\text { Ln No. of Firms (less } \\
\text { restrictive countries) }\end{array}$ & 418 & 4.045 & -0.499 & 0.000 & 0.986 \\
$\begin{array}{c}\text { Ln No. of Firms (more } \\
\text { restrictive countries) }\end{array}$ & 418 & 0.067 & -0.011 & & \\
$\begin{array}{c}Z \text {-score (less restrictive } \\
\text { countries) }\end{array}$ & & 0.056 & & \\
$\begin{array}{c}Z \text {-score (more restrictive } \\
\text { countries) }\end{array}$ & & & & & \\
\hline
\end{tabular}

In this table, we compare the portfolio diversification and risk-taking of banks across two sub-samples of countries with less and more restrictive regulations on ownership of banks. We employ a propensity score matching procedure to identify a control sample of banks headquartered in countries with very stringent regulation and that exhibit no observable differences in characteristics relative to the banks that are headquartered in countries with less restrictive regulation. The propensity score is estimated using all banks characteristics that we included in the previous regression analyses except portfolio diversification. To ensure that the two groups of banks are sufficiently similar, we require that the maximum difference between the propensity score of the bank in a less restrictive country and that of its matching peer does not exceed $0.1 \%$ in absolute value. We then compare the largest shareholders portfolio diversification and the risk-taking between the two groups. Risk-taking is measured as the $Z$-score, that is, the ratio of volatility of $R O A\left(\sigma_{i, R O A}\right)$ to the sum of average return on assets (avgROA) and average capital asset ratio (avgCAR), requiring at least five consecutive observations of ROA. Portfolio diversification is measured as the $L n$ No. of Firms.

responses for Survey I were given during 1998-1999, but a number of them were received in 2000 as well; while Survey II was conducted in early 2003 to assess the state of regulation as of the end of 2002. Based on this information, we consider the 1999-2000 period as the years pre-change and the 2003-2004 period as the years post-change, reasonably assuming that any change in the regulations on ownership of banks occurred between 2001 and 2002. We also require banks to have available data on portfolio diversification and Z-score in all years pre- and post-change. We are able to retrieve data on 354 banks headquartered in those countries affected by a negative change in regulation. We expect that more stringent regulations on holding stakes in a bank are likely to decrease the average portfolio diversification of bank largest shareholders. As such, if large shareholders do influence bank risk-taking decisions, then the risk-taking of the banks they own should decrease. Consistent with our expectations, Table 6 shows that on average in the years post-change the portfolio diversification of largest shareholders significantly decreases as Ln No of Firms decreases from 3.17 to 3 (with a $p$-value of about 0.06) which corresponds to an average decrease of about 3 companies in the shareholder portfolio. More importantly, $Z$-score decreases from 0.066 to 0.056 with a $p$-value of about 0.003 .

\subsubsection{Reverse causality}

Although previous tests seem to suggest that largest shareholders do affect bank risk-taking, there could be still concerns of potential reverse causality. For instance, a channel for reverse causality could

Table 6

Changes in regulatory restrictiveness of ownership of banks.

\begin{tabular}{lcccc}
\hline & No. of observations & Mean & $\Delta$ Mean (more restrictive - less restrictive) & $p$-Value of diff. \\
\hline Ln No. of Firms (pre-change) & 354 & 3.169 & -0.167 & 0.059 \\
Ln No. of Firms (post-change) & & 3.002 & -0.010 & 0.003 \\
Z-score (pre-change) & 354 & 0.066 & 0.056 & \\
Z-score (post-change) & & &
\end{tabular}

This table reports tests for differences in the mean of changes in risk-taking and portfolio diversification before and after a change in the regulatory restrictiveness of ownership of banks between Survey I and Survey II (Barth et al., 2008). We focus on changes that make the regulations on ownership of banks more stringent over time since these are the most frequent events in our sample. Risk-taking is measured as the $Z$-score, that is, the ratio of volatility of $R O A\left(\sigma_{i, R O A}\right)$ to the sum of average return on assets ( $\operatorname{avgROA}$ ) and average capital asset ratio ( $\operatorname{avgCAR}$ ), requiring at least five consecutive observations of ROA. Portfolio diversification is measured as the Ln No. of Firms. 
be that a shareholder planning to invest in a bank with a certain risk profile would accordingly make portfolio diversification adjustments in advance. Alternatively, the bank's largest shareholders may increase (decrease) the level of diversification of their portfolios following a shock that raises (lowers) the risk profile of the bank they own. We would still observe a positive relation between risk-taking and portfolio diversification, as in our main findings. However, the causality would run from bank risktaking decisions to portfolio diversification, not the other way round. To further address this concern we employ two different tests.

First, we adopt the instrumental variable (IV) technique to address the potential reverse causality issue in the baseline models. We use the Average Diversification of all other bank shareholders in the same country and year where the bank is headquartered to extract the "natural" tendency to diversify across investors within the same geographical area. The richness of our database allows us to exploit the cross-sectional variation of shareholder ability to diversify portfolio across European countries. This measure is close in spirit to Laeven and Levine (2009) and Faccio et al. (2011). It seems unlikely that the average diversification of shareholders investing in other banks in the same country of the bank of interest has any direct impact on the risk-taking decisions of that bank.

Table 7 Panel A reports the results of the second-stage regressions that include the predicted values of portfolio diversification proxies estimated in the first stage. For the first-stage regressions we report only the estimates of the instrumental variables (first-stage regressions include also all other control variables). Across all models Average Portfolio Diversification is significantly correlated to each proxy of portfolio diversification, with the expected sign. Further, both the values of the $F$-tests of the excluded instruments (ranging from 109.62 to 202.27) and the values of the partial $R$-squared of excluded instruments (not close to zero) indicate that these are not weak instruments (Bound et al., 1995; Staiger and Stock, 1997, show that a value of the first-stage $F$ statistics below 10 and the $R$-squared close to zero are suggestive of weak instruments). Most importantly, the estimated coefficients of all proxies of portfolio diversification in the second-stage regressions are still positive and statistically significant.

A potential concern with the above instrument is that the same omitted variable could explain the portfolio diversification of all other bank shareholders and the risk-taking decisions of banks in the same country and year (e.g. this instrument may capture the financial development within each country that directly and indirectly might affect the risk-taking decisions of the bank of interest).

The inclusion of Country $\times$ Year fixed effect should help reduce this concern. Nonetheless, as a further attempt to limit this issue, we modify the previous instrument as follows: within the same country and year, for banks with above-average (below-average) risk-taking, we compute the diversification of shareholders of banks which exhibit below-average (above-average) risk-taking. Thus, for an omitted variable to explain our results, this variable would need to explain: (1) portfolio diversification of the shareholder of the bank of our interest; (2) portfolio diversification of other bank shareholders; (3) above-average risk-taking for the bank of our interest; and at the same time (4) below-average risk-taking of all the other banks in the same country and year.

Results in Panel B confirm the positive and significant impact of shareholder diversification on bank risk-taking decisions across all our proxies of portfolio diversification.

As a second test to control for potential reverse causality, we exploit the event of a bank credit rating downgrade as a shock that is likely to affect risk-taking. If there is a feedback effect from risk-taking to portfolio diversification, then after the downgrade and the change in risk-taking, we should observe a change in the portfolio diversification of the bank largest shareholder.

To identify downgrades in credit rating, we use the Fitch Long Term Senior-Debt credit ratings from 2001 to 2006 as provided by Bankscope. Since we aim to capture only idiosyncratic shocks to bank risks, we exclude the years of the sub-prime financial crisis that most likely had an effect on both bank risk-taking decisions and shareholder portfolio diversification simultaneously. We define a downgrade event as being when a bank in a certain year experiences a negative change of at least one notch from its previous rating. The initial sample size of banks with at least two reported credit ratings between 2001 and 2006 is 2,025. We identify 615 downgrade events. Finally, we require banks to have available information on $Z$-score and portfolio diversification one year before and after the downgrade event. We are left with a total of 57 instances. 
Table 7

Instrumental variable regressions.

\begin{tabular}{|c|c|c|c|}
\hline \multicolumn{4}{|c|}{ Panel A } \\
\hline \multicolumn{4}{|c|}{ Second-stage regressions } \\
\hline \multirow{3}{*}{ Portfolio diversification (fitted) } & Ln No. of Firms & $(1-\mathrm{HI})$ & -Correlation \\
\hline & $0.117^{* * *}$ & $0.975^{* * *}$ & $1.704^{* * *}$ \\
\hline & {$[0.004]$} & {$[0.000]$} & {$[0.000]$} \\
\hline \multirow[t]{2}{*}{ Cash flow rights } & $0.002^{* * * *}$ & $0.002^{* * * *}$ & $0.002^{* * *}$ \\
\hline & {$[0.007]$} & {$[0.005]$} & {$[0.000]$} \\
\hline \multirow[t]{2}{*}{ Managerial ownership } & 0.004 & 0.006 & 0.006 \\
\hline & {$[0.691]$} & {$[0.522]$} & {$[0.514]$} \\
\hline \multirow[t]{2}{*}{ Size } & $-0.025^{*}$ & $-0.026^{* *}$ & $-0.032^{* *}$ \\
\hline & {$[0.066]$} & {$[0.039]$} & {$[0.016]$} \\
\hline \multirow[t]{2}{*}{ CAR } & $-0.822^{* * *}$ & $-0.773^{* * *}$ & $-0.741^{* * *}$ \\
\hline & {$[0.000]$} & {$[0.000]$} & {$[0.000]$} \\
\hline \multirow[t]{2}{*}{ Net interest marginal revenue } & $-0.866^{* * *}$ & $-0.857^{* * *}$ & $-0.792^{* * *}$ \\
\hline & {$[0.000]$} & {$[0.000]$} & {$[0.000]$} \\
\hline \multirow[t]{2}{*}{ Interest activity } & $-0.046^{* * *}$ & $-0.046^{* * *}$ & $-0.035^{* * *}$ \\
\hline & {$[0.000]$} & {$[0.000]$} & {$[0.000]$} \\
\hline \multirow{2}{*}{ Loan loss provision } & $1.097^{* * * *}$ & $1.170^{* * * *}$ & $0.994^{* * * *}$ \\
\hline & {$[0.000]$} & {$[0.000]$} & {$[0.000]$} \\
\hline \multirow{4}{*}{$\begin{array}{l}\text { Country } \times \text { Year fixed effects } \\
\text { No. of observations }\end{array}$} & $-0.193^{* * *}$ & $-0.169^{* * *}$ & $-0.161^{* * *}$ \\
\hline & {$[0.000]$} & {$[0.000]$} & {$[0.001]$} \\
\hline & Yes & Yes & Yes \\
\hline & 4,768 & 4,768 & 4,768 \\
\hline \multicolumn{4}{|c|}{ First-stage regressions } \\
\hline Portfolio diversification & Ln No. of Firms & $(1-\mathrm{HI})$ & -Correlation \\
\hline \multirow{2}{*}{ Average portfolio diversification (same country/year) } & $0.745^{* * *}$ & $0.725^{* * *}$ & $0.476^{* * * *}$ \\
\hline & {$[0.000]$} & {$[0.000]$} & {$[0.000]$} \\
\hline \multirow{2}{*}{$\begin{array}{l}\text { Partial } R \text {-squared of excluded instruments } \\
F \text {-test of excluded instruments }\end{array}$} & 0.055 & 0.037 & 0.038 \\
\hline & 202.273 & 154.872 & 109.6243 \\
\hline \multicolumn{4}{|c|}{ Panel B } \\
\hline \multicolumn{4}{|c|}{ Second-stage regressions } \\
\hline \multirow[t]{2}{*}{ Portfolio diversification (fitted) } & $0.474^{* * *}$ & $3.624^{* * *}$ & $7.545^{* * *}$ \\
\hline & {$[0.000]$} & {$[0.000]$} & {$[0.000]$} \\
\hline \multirow[t]{2}{*}{ Cash flow rights } & $0.007^{* * * *}$ & $0.004^{* * * *}$ & $0.009^{* * *}$ \\
\hline & {$[0.000]$} & {$[0.000]$} & {$[0.000]$} \\
\hline \multirow[t]{2}{*}{ Managerial ownership } & $0.014^{* *}$ & $0.020^{* * * * *}$ & $0.016^{* *}$ \\
\hline & [0.039] & {$[0.003]$} & {$[0.022]$} \\
\hline \multirow[t]{2}{*}{ Size } & $-0.123^{* * *}$ & $-0.125^{* * *}$ & $-0.187^{* * *}$ \\
\hline & {$[0.000]$} & {$[0.000]$} & {$[0.000]$} \\
\hline \multirow[t]{2}{*}{ CAR } & $-0.929^{* * *}$ & $-0.725^{* * *}$ & $-0.683^{* * *}$ \\
\hline & {$[0.000]$} & {$[0.002]$} & {$[0.005]$} \\
\hline \multirow[t]{2}{*}{ Net interest marginal revenue } & $-0.866^{* * *}$ & $-0.804^{* * *}$ & $-0.562^{* * *}$ \\
\hline & {$[0.000]$} & {$[0.000]$} & {$[0.000]$} \\
\hline Interest activity & $-0.036^{* * *}$ & $-0.043^{* * *}$ & 0.01 \\
\hline & {$[0.000]$} & {$[0.000]$} & {$[0.501]$} \\
\hline Loan loss provision & $1.495^{* * *}$ & $1.720^{* * * *}$ & $1.337^{* * *}$ \\
\hline & {$[0.000]$} & {$[0.000]$} & {$[0.000]$} \\
\hline Private dummy & $-0.316^{* * *}$ & $-0.219^{* * *}$ & $-0.297^{* * *}$ \\
\hline & {$[0.000]$} & {$[0.000]$} & {$[0.000]$} \\
\hline Country $\times$ Year fixed effects & Yes & Yes & Yes \\
\hline No. of observations & 4,728 & 4,721 & 4,721 \\
\hline
\end{tabular}


Table 7 (continued)

\begin{tabular}{llll}
\hline & First-stage regressions & & \\
Portfolio diversification & Ln No. of Firms & $(1-\mathrm{HI})$ & - Correlation \\
Average portfolio diversification of below-median risk-taking & $-0.888^{* * *}$ & $-0.982^{* * *}$ & $-0.998^{* * *}$ \\
$\quad$ banks (same country/year) & {$[0.000]$} & {$[0.000]$} & {$[0.000]$} \\
Partial $R$-squared of excluded instruments & 0.026 & 0.022 & 0.033 \\
F-test of excluded instruments & 121.85 & 103.77 & 129.41 \\
\hline
\end{tabular}

This table reports instrumental variable panel regression results. In the second-stage regressions, the dependent variable is the LnZ-score. Z-score is the ratio of volatility of ROA $\left(\sigma_{i, R O A}\right)$ to the sum of average return on assets (avgROA) and average capital asset ratio (avgCAR). Each component of the Z-score is calculated over five consecutive year overlapping periods, that is, 2000-2004, 2001-2005, 2002-2006, 2003-2007 and 2004-2008. All independent variables are taken at the beginning of each overlapping period. Please refer to Table 1 for the definitions of all variables. In Panel A, we use Average Portfolio Diversification (same country/ year), defined as the average portfolio diversification of large shareholders across all other banks in the same country and year as the bank in question, as instrument for the portfolio diversification measure. In Panel B, we modify the previous instrument as follows: within the same country and year, for banks with above-average (below-average) risk-taking, we compute the diversification of shareholders of banks which exhibit below-average (above-average) risk-taking (Average Portfolio Diversification of below-median risk-taking banks (same country/year)). All regressions include Country $\times$ Year fixed effects, and standard errors are correct for heteroskedasticity. P-values are reported in brackets.

${ }^{*}$ Report the statistical significance at the $10 \%$ level.

** Report the statistical significance at the $5 \%$ level.

**** Report the statistical significance at the $1 \%$ level.

Table 8

Credit rating downgrades.

\begin{tabular}{lcccc}
\hline Variable & Obs (Bank-years) & Mean & $\Delta$ Mean (After-Before) & $p$-Value $(\Delta$ Mean $=0)$ \\
\hline Z-score (pre-downgrade) & 57 & 0.110 & & 0.002 \\
Z-score (post-downgrade) & & 0.193 & 0.083 & 0.981 \\
Ln No of Firms (pre-downgrade) & 57 & 3.233 & & 0.011 \\
Ln No of Firms (post-downgrade) & & 3.222 &
\end{tabular}

This table reports tests for differences in the mean of changes in risk-taking and portfolio diversification before and after a downgrade event. A downgrade event is identified when a bank in a certain year experiences a negative change in its credit rating of at least one notch from the previous available rating. Risk-taking is measured as the Z-score, that is, the ratio of volatility of $R O A\left(\sigma_{i, R O A}\right)$ to the sum of average return on assets $(\operatorname{avgROA})$ and average capital asset ratio (avgCAR), requiring at least five consecutive observations of ROA. Portfolio diversification is measured as the Ln No. of Firms.

Table 8 reports results of the tests of difference in means for both Z-score and Ln No of Firms before and after the downgrade. As expected, we observe a significant increase in insolvency (risk-taking) after the downgrade, from 0.110 to 0.193 in the $Z$-score with a $p$-value of less than 0.01 . However, when we turn to the change in portfolio diversification, the largest shareholders do not seem to increase the level of diversification of their portfolios significantly. The $p$-value of the change in $L n$ No. of Firms, from 3.233 to 3.222, is 0.981 .

A potential criticism of this test could be that largest shareholders would preventively adjust their portfolio diversification in anticipation of the downgrade event. This would imply no change in portfolio diversification afterwards, as the change already occurred before the downgrade. To rule out this possibility, we look for those instances where portfolio diversification is available further back in time and we calculate the change in the average portfolio diversification in the two years before the event. Although this reduces the sample to 23 cases, we find no significant change ( $p$-value around 0.33 ), further suggesting that there are no feedback effects from risk-taking to portfolio diversification decisions.

We acknowledge that each of the tests presented so far has its own limitations and, therefore, one cannot fully control for the endogeneity issue. Nonetheless, all our attempts form a consistent body of evidence suggesting that portfolio diversification of the largest shareholder leads to banks taking riskier decisions. 


\section{Robustness tests: shareholders' incentives}

\subsection{Tunnelling}

A potential concern with the interpretation of our results is that the positive relation between bank risk-taking and largest shareholder diversification might be suggestive of expropriation, i.e. tunnelling: a large shareholder may siphon resources out of the bank where he/she has fewer cash flow rights to benefit other firms where he/she owns more cash flow rights (e.g. Bertrand et al., 2002; John et al., 2008; Johnson et al., 2000). For instance, she may induce the bank she controls to undertake riskier strategies at the expenses of bank's minority shareholders to tunnel the gains out toward her other companies. As a result, over time, the performance of the bank where she holds fewer cash flow rights would be more volatile.

Previous studies suggest that the tunnelling effect may occur when the largest shareholder's control rights do not fully coincide with her cash flow rights. In particular, the larger the difference between the largest shareholder's control rights and cash flow rights, the higher the risk of tunnelling (e.g. Claessens et al., 2002; Bennedsen and Nielsen, 2010). We also expect that this effect might be further exacerbated if the largest shareholder is more diversified (i.e. she owns more companies to which resources can be tunnelled).

To test this alternative interpretation, we construct the difference between Control Rights and Cash Flow Rights of each largest shareholder in each bank (Wedge). Then we augment our baseline model with Wedge and the interaction between Wedge and the portfolio diversification proxy. If our baseline results reflect a tunnelling story, then we should expect: (1) more risk-taking in those banks where the largest shareholders hold fewer cash flow rights than control rights (i.e. larger Wedge); and (2) more risk-taking in those where the wedge is larger and the largest shareholder is also more diversified (i.e. larger interaction between Wedge and portfolio diversification).

Results in Table 9 Panel A do not lend support to this story. In column (1) the estimated coefficient of Wedge is negative and not statistically significant and so is the estimated coefficient of the interaction term between Wedge and portfolio diversification in column (2). Results do not change if we replace the variable Wedge with a dummy equal to 1 if there is a positive difference between control rights and cash flow rights, and 0 otherwise (Wedge dummy, columns (3) and (4)). Most importantly, across all models portfolio diversification remains positive and strongly significant.

\subsection{Shareholder's types}

A number of studies in the banking literature investigate the role played by the ownership type on bank's decisions and performance, finding mixed results. In our models we include shareholders fixed effect that should capture all the time invariant characteristics of shareholders, including their type. Nonetheless, we take one step further and investigate whether shareholders' type might explain our baseline results. To this end we perform two separate analyses. First, we consider whether the largest shareholder is headquartered in a country different from the headquarter country of the bank she controls. That is, we control for whether foreign-owned banks have different risk preferences than domestic ones.

The theoretical arguments related to the risk-taking incentives of foreign-owned banks are twofold. On the one hand, foreign banks that operate abroad are more likely to be better diversified. Claessens and van Horen (2012), for instance, state that foreign banks have more diversified funding bases (they can have access to liquidity through their parent company) that allow them to reduce their funding costs. This ultimately would increase their incentive to take more risks than comparable domestic banks.

On the other hand, foreign banks are likely to face more asymmetric information than local banks when it comes to processing "soft" information about local conditions, and to have more management difficulties due to geographical distance and/or multiple economic/regulatory environments (Berger et al., 2005). This would lead foreign banks towards having more prudent business strategies even when they operate abroad ("act abroad as if at home"). For instance, foreign banks would be more 
Table 9

Robustness tests: shareholders' incentives.

\begin{tabular}{|c|c|c|c|c|}
\hline Z-score & $(1)$ & $(2)$ & (3) & $(4)$ \\
\hline \multicolumn{5}{|c|}{ Panel A. Tunnelling } \\
\hline \multirow[t]{3}{*}{ Ln No. of Firms } & $0.0478^{* * *}$ & $0.0497^{* * *}$ & $0.0420^{* *}$ & $0.0466^{* * *}$ \\
\hline & {$[0.0087]$} & {$[0.0074]$} & {$[0.0285]$} & {$[0.0223]$} \\
\hline & $3.68 \%$ & $3.82 \%$ & $3.23 \%$ & $3.58 \%$ \\
\hline \multirow[t]{2}{*}{ Wedge } & -0.0043 & 0.0023 & & \\
\hline & {$[0.4189]$} & {$[0.8676]$} & & \\
\hline \multirow[t]{2}{*}{ Wedge $\times$ Ln No. of Firms } & & -0.002 & & \\
\hline & & {$[0.6020]$} & & \\
\hline \multirow[t]{2}{*}{ Wedge dummy } & & & 0.0212 & 0.0947 \\
\hline & & & [0.7319] & {$[0.4754]$} \\
\hline \multirow[t]{2}{*}{ Wedge dummy $\times$ Ln No. of Firms } & & & & -0.0227 \\
\hline & & & & [0.5398] \\
\hline \multirow[t]{2}{*}{ Cash flow rights } & 0.0008 & 0.0008 & 0.001 & 0.001 \\
\hline & {$[0.3183]$} & {$[0.3198]$} & {$[0.2366]$} & {$[0.2552]$} \\
\hline \multirow[t]{2}{*}{ Managerial ownership } & 0.001 & 0.0011 & 0.0009 & 0.0012 \\
\hline & {$[0.8932]$} & {$[0.8884]$} & {$[0.9061]$} & [0.8819] \\
\hline \multirow[t]{2}{*}{ Size } & $-0.0322^{*}$ & $-0.0323^{*}$ & -0.0292 & -0.0296 \\
\hline & {$[0.0708]$} & {$[0.0702]$} & {$[0.1058]$} & {$[0.1010]$} \\
\hline \multirow[t]{2}{*}{ CAR } & $-0.6795^{* *}$ & $-0.6840^{* *}$ & $-0.6763^{* *}$ & $-0.6838^{* *}$ \\
\hline & {$[0.0243]$} & {$[0.0235]$} & {$[0.0255]$} & {$[0.0242]$} \\
\hline \multirow[t]{2}{*}{ Net interest marginal revenue } & $-0.8208^{* * * *}$ & $-0.8194^{* * * *}$ & $-0.8236^{* * * *}$ & $-0.8220^{* * * *}$ \\
\hline & {$[0.0000]$} & {$[0.0000]$} & {$[0.0000]$} & {$[0.0000]$} \\
\hline \multirow[t]{2}{*}{ Interest activity } & $-0.0241^{*}$ & $-0.0242^{*}$ & $-0.0248^{*}$ & $-0.0249^{*}$ \\
\hline & {$[0.0826]$} & {$[0.0820]$} & {$[0.0740]$} & {$[0.0738]$} \\
\hline \multirow[t]{2}{*}{ Loan loss provision } & $0.6425^{*}$ & $0.6361^{*}$ & $0.6388^{*}$ & $0.6259^{*}$ \\
\hline & {$[0.0717]$} & {$[0.0747]$} & {$[0.0735]$} & {$[0.0806]$} \\
\hline \multirow[t]{2}{*}{ Private dummy } & -0.0044 & -0.0044 & -0.0056 & -0.0069 \\
\hline & {$[0.9502]$} & {$[0.9493]$} & {$[0.9365]$} & {$[0.9211]$} \\
\hline \multirow[t]{2}{*}{ Intercept } & $-1.7153^{* *}$ & $-1.7303^{* *}$ & $-1.7771^{* *}$ & $-1.8298^{* * *}$ \\
\hline & {$[0.0142]$} & {$[0.0130]$} & {$[0.0111]$} & {$[0.0095]$} \\
\hline Shareholder fixed effects & Yes & Yes & Yes & Yes \\
\hline Country $\times$ Year fixed effects & Yes & Yes & Yes & Yes \\
\hline Adjusted $R$-squared & 0.32 & 0.32 & 0.32 & 0.32 \\
\hline No. of observations & 4,768 & 4,768 & 4,768 & 4,768 \\
\hline \multicolumn{5}{|c|}{ Panel B. Shareholders Types } \\
\hline \multirow[t]{3}{*}{ Ln No. of Firms } & $0.0546^{* * * *}$ & $0.0440^{* *}$ & $0.0450^{* * *}$ & $0.0455^{* * *}$ \\
\hline & {$[0.0027]$} & {$[0.0125]$} & {$[0.0112]$} & {$[0.0104]$} \\
\hline & $4.20 \%$ & $3.39 \%$ & $3.47 \%$ & $3.50 \%$ \\
\hline Foreign & $-0.1389^{* *}$ & & & \\
\hline & [0.0303] & & & \\
\hline Financial shareholder & & 0.0503 & & \\
\hline & & {$[0.4478]$} & & \\
\hline Institutional investor & & & $0.1499^{*}$ & 0.0818 \\
\hline & & & {$[0.0098]$} & {$[0.5585]$} \\
\hline Bank & & & 0.0107 & -0.0571 \\
\hline & & & [0.8803] & {$[0.6545]$} \\
\hline Insurance & & & 0.0838 & 0.0162 \\
\hline & & & {$[0.4354]$} & {$[0.9146]$} \\
\hline Non-financial company & & & & -0.0767 \\
\hline & & & & [0.5469] \\
\hline Cash flow rights & 0.0008 & 0.0008 & 0.0011 & 0.0011 \\
\hline & {$[0.3158]$} & {$[0.2998]$} & {$[0.1945]$} & {$[0.1930]$} \\
\hline Managerial ownership & 0.0016 & 0.001 & 0.0006 & 0.0008 \\
\hline & {$[0.8343]$} & {$[0.8956]$} & {$[0.9364]$} & {$[0.9165]$} \\
\hline Size & $-0.0341^{*}$ & $-0.0300^{*}$ & $-0.0310^{*}$ & $-0.0308^{*}$ \\
\hline & {$[0.0536]$} & {$[0.0879]$} & {$[0.0776]$} & [0.0799] \\
\hline CAR & $-0.6694^{* *}$ & $-0.6747^{* *}$ & $-0.7061^{* *}$ & $-0.7046^{* *}$ \\
\hline & {$[0.0263]$} & {$[0.0254]$} & {$[0.0195]$} & {$[0.0198]$} \\
\hline
\end{tabular}

(continued on next page) 


\begin{tabular}{|c|c|c|c|c|}
\hline Net interest marginal revenue & $\begin{array}{l}-0.8202^{* * *} \\
{[0.0000]}\end{array}$ & $\begin{array}{l}-0.8224^{* * *} \\
{[0.0000]}\end{array}$ & $\begin{array}{l}-0.8177^{* * *} \\
{[0.0000]}\end{array}$ & $\begin{array}{l}-0.8168 \text { *** } \\
{[0.0000]}\end{array}$ \\
\hline \multirow[t]{2}{*}{ Interest activity } & $-0.0247^{*}$ & $-0.0247^{*}$ & $-0.0246^{*}$ & $-0.0247^{*}$ \\
\hline & {$[0.0750]$} & {$[0.0753]$} & [0.0747] & {$[0.0743]$} \\
\hline \multirow[t]{2}{*}{ Loan loss provision } & $0.6239^{*}$ & $0.6418^{*}$ & $0.6342^{*}$ & $0.6292^{*}$ \\
\hline & {$[0.0790]$} & {$[0.0723]$} & [0.0747] & {$[0.0775]$} \\
\hline \multirow[t]{2}{*}{ Private dummy } & -0.0008 & -0.0046 & -0.0045 & -0.0039 \\
\hline & [0.9913] & {$[0.9470]$} & {$[0.9483]$} & [0.9549] \\
\hline \multirow[t]{2}{*}{ Intercept } & $-1.5571^{* *}$ & $-1.7826^{* *}$ & $-1.7751^{* * *}$ & $-1.7082^{* *}$ \\
\hline & {$[0.0315]$} & {$[0.0102]$} & {$[0.0104]$} & {$[0.0151]$} \\
\hline Shareholder fixed effects & Yes & Yes & Yes & Yes \\
\hline Country $\times$ Year fixed effects & Yes & Yes & Yes & Yes \\
\hline Adjusted $R$-squared & 0.32 & 0.32 & 0.32 & 0.32 \\
\hline No. of observations & 4,768 & 4,768 & 4,768 & 4,768 \\
\hline \multicolumn{5}{|c|}{ Panel C. Shareholders' control } \\
\hline \multirow{4}{*}{$\begin{array}{l}\text { Z-score } \\
\text { Ln No. of Firms }\end{array}$} & \multicolumn{2}{|c|}{$>10 \%$ Control Rights } & \multicolumn{2}{|r|}{$>20 \%$ Control Rights } \\
\hline & \multirow{2}{*}{\multicolumn{2}{|c|}{$\begin{array}{l}0.0247^{* *} \\
{[0.0303}\end{array}$}} & & $\begin{array}{l}>20 \% \text { Control Rights } \\
0.0285^{* *}\end{array}$ \\
\hline & & & & {$[0.0363]$} \\
\hline & \multicolumn{2}{|c|}{$\begin{array}{l}{[0.0303]} \\
1.90 \%\end{array}$} & & $2.19 \%$ \\
\hline \multirow{2}{*}{ Cash Flow Rights } & \multicolumn{2}{|c|}{$0.0013^{* * *}$} & & $0.0012^{* *}$ \\
\hline & \multicolumn{2}{|c|}{$[0.0114]$} & & {$[0.0470]$} \\
\hline \multirow[t]{2}{*}{ Managerial Ownership } & \multicolumn{2}{|c|}{$0.0097^{* * *}$} & & \multirow{2}{*}{$\begin{array}{l}0.0118^{* * *} \\
{[0.0109]}\end{array}$} \\
\hline & \multicolumn{2}{|c|}{$[0.0118]$} & & \\
\hline \multirow[t]{2}{*}{ Size } & \multicolumn{2}{|c|}{$-0.0282^{* * *}$} & & $-0.0317^{* *}$ \\
\hline & \multicolumn{2}{|c|}{ [0.0089] } & & {$[0.0132]$} \\
\hline CAR & & & & $-0.9503^{* * *}$ \\
\hline & & & & {$[0.0000]$} \\
\hline Net interest marginal revenue & & & & $-0.6369 * * *$ \\
\hline & & & & {$[0.0000]$} \\
\hline Interest activity & & & & $-0.0427^{* * *}$ \\
\hline & & & & {$[0.0002]$} \\
\hline Loan loss provision & & & & $0.9828^{* * * *}$ \\
\hline & & & & {$[0.0002]$} \\
\hline Private dummy & & & & $-0.0904^{*}$ \\
\hline & & & & {$[0.0838]$} \\
\hline Intercept & & & & $-1.4586^{* * *}$ \\
\hline & & & & {$[0.0000]$} \\
\hline Shareholder fixed effects & & & & Yes \\
\hline Country $\times$ Year fixed effects & & & & Yes \\
\hline Adjusted $R$-squared & & & & 0.11 \\
\hline No. of observations & & & & 2,742 \\
\hline
\end{tabular}

This table reports panel data results where the dependent variable is the $\operatorname{Ln} Z$-score. Z-score is the ratio of volatility of ROA $\left(\sigma_{i, R O A}\right)$ to the sum of average return on assets (avgROA) and average capital asset ratio (avgCAR). Each component of the Z-score is calculated over five consecutive year overlapping periods, that is, 2000-2004, 2001-2005, 2002-2006, 2003-2007 and 20042008. All independent variables are taken at the beginning of each overlapping period. Please refer to Table 1 for the definitions of all variables. All regressions include Shareholder as well as Country $\times$ Year fixed effects, and standard errors are correct for heteroskedasticity. The economic impact of each portfolio diversification proxy is reported below the corresponding $p$-value in bold. The economic impact is calculated as the percentage change of the average bank risk-taking in response to a standard deviation increase of the portfolio diversification variable. $P$-values are reported in brackets.

* Report the statistical significance at the $10 \%$ level.

** Report the statistical significance at the $5 \%$ level.

*** Report the statistical significance at the $1 \%$ level.

likely to have banking relationships with larger, older and more transparent firms than domestic banks, suggestive of lower risk-taking.

The empirical evidence is mixed. On the one hand, a number of studies using bank-level data show that foreign banks are in general more conservative than domestic ones having higher risk-based capital ratios (Crystal et al., 2002) and lower distance to default (Buch et al., 2011; Drakos et al., in press). They tend to "cherry-pick", i.e. lend to larger, older and more transparent firms (e.g. Mian, 2006; Berger et al., 2008; Gormley, 2010; Giannetti and Ongena, 2012), and lend mortgages to clients more likely to be formally employed, with more personal assets, and richer than clients of domestic banks (Beck and Brown, in press). These findings are all suggestive of fewer risk-taking decisions by 
foreign-owned banks. On the other hand, studies at country level find that larger market shares of foreign banks are associated with higher bank lending to GDP ratios (e.g. Berger et al., 2004) and with lower financing obstacles for all companies, including the small and medium-sized ones (e.g. Clarke et al., 2006). Recent findings using firm-level data seem to support these results, showing how the home-country regulations of foreign banks shape their lending behaviour when they operate abroad (Ongena et al., 2013). ${ }^{21}$

To retrieve information on the country of origin of each ultimate shareholder of each bank in our sample we use first the information provided both in Bankscope and Amadeus. When this information is not available, we employ several internet-based sources that provide country-specific lists of companies registered in each country. ${ }^{22}$ As a last resort, when we cannot identify the country of origin with these sources, we use Google and LinkedIn. Then we construct a dummy, Foreign, equal to 1 if the country of origin of the largest shareholder is different from the country where the bank she controls is headquartered and zero otherwise. In our sample about $32 \%$ of bank-year observations have a foreign ultimate largest shareholder. ${ }^{23}$ Foreign-owned banks are particularly dominant in Eastern European countries where about $56 \%$ of bank ultimate shareholders are headquartered abroad, in line with previous evidence (e.g. Beck and Brown, in press).

Table 9 Panel B column (1) reports the estimates of the baseline model with Ln No. of Firms as a proxy for portfolio diversification augmented by the dummy Foreign. The estimated coefficient of the dummy Foreign is negative and statistically significant suggesting that, at least for our sample, foreign-owned banks seem to take less risky decisions than domestic ones, supporting and further contributing to the empirical literature of cherry-picking by foreign banks. Most importantly, after controlling for the largest shareholder origin, our proxy of portfolio diversification still remains positive and strongly significant.

The second analysis we perform to control whether shareholders' type might explain our baseline results looks at different shareholder categories. The number of studies in banking literature that investigate the role played by shareholder categories in bank's decisions is more limited than that in corporate finance literature. Most of these studies focus on one particular class of shareholders (i.e. institutional investors), with the exception of Barry et al. (2011), who attempt to differentiate the risk-taking incentives across different types of shareholders.

The theoretical argument more often associated with each category of shareholder is related to portfolio diversification. As mentioned in the introduction, previous studies in the banking literature have used shareholder types as a proxy for wealth diversification. However, the empirical findings are mixed. On the one hand, institutional investors (including mutual, pension and hedge funds), assumed to be very well diversified shareholders, are associated with more risk-taking choices (e.g. Barry et al., 2011; Erkens et al., 2012; Cheng et al., 2015). On the other hand, Knopf and Teall (1996) and Cebenoyan et al. (1999) show an inverse relationship between risk-taking and the level of institutional shareholding. Further, banks and insurance companies are also assumed to be well diversified shareholders. Nonetheless, several studies in corporate finance literature show that these two categories have different characteristics from institutional investors, such as longer investment horizons (e.g. Hotchkiss and Strickland, 2003; Gaspar et al., 2005) and/or more business ties with the companies they invest in (e.g. Brickley et al., 1988; Bushee, 1998; Almazan et al., 2005; Chen et al., 2007). This would lead to the prediction that banks and insurance companies are more conservative than other institutional investors when it comes to risk-taking preferences (e.g. Bennett et al., 2003). Indeed, Barry et al. (2011) provide evidence that banks' stakes in other banks are associated with a decrease in asset and default risk. Finally, among non-financial institutions, both non-financial firms and

\footnotetext{
${ }^{21}$ For extensive empirical literature review of the differences in performance, efficiency and lending decisions between foreign and domestic banks see Degryse et al. (2009) and Claessens and van Horen (2012).

${ }^{22}$ Some examples are http://investing.businessweek.com/, http://norwaycompanies.eu/, www.companieshouse.gov.uk/, www.firmenabc.at/, www.firmendb.de, http://rus.bizdirlib.com/.

23 The information on bank ownership collected by Barth et al. (2006, 2008, and 2013) in three consecutive surveys (Survey I in 1998/1999, Survey II in 2003, and Survey III in 2007) shows that across countries in our sample and across the 1999-2006 period the average percentage of bank assets in foreign-owned banks is about $37 \%$ (question 3.8 ).
} 
family/individuals tend to be less diversified than financial companies (e.g. Faccio et al., 2011). In fact, previous evidence seems to suggest that when banks are owned by families they do not increase risktaking (e.g. Laeven and Levine, 2009; Barry et al., 2011).

To retrieve information on the category of each ultimate shareholder in our sample we use first the information provided both in Bankscope and Amadeus. Starting with the 2006 DVD, Bankscope provides information on the shareholder type for a sub-sample of banks only. When it clearly identifies a type of shareholder, we use this information to classify shareholders in the previous years. When this information is either not specific or not available, we employ the same internet-based sources as above to classify the ultimate shareholders in our sample. ${ }^{24}$ We are able to identify five categories: Institutional Investor (including pension, mutual and hedge fund), Bank, Insurance, Non-Financial Company and Family (including family and individual). We construct a dummy, Financial Shareholder, equal to 1 if the ultimate largest shareholder is either classified as an Institutional investor, Bank or Insurance company, and zero otherwise. Further, for each of the five categories above, we construct a dummy equal to 1 if the ultimate largest shareholder is classified in that particular category, and zero otherwise.

The large majority of banks in our sample, 70\%, are owned by a financial shareholder. Among financial shareholders, banks play the major role, being the largest owners of about $48 \%$ of banks, followed by institutional investors and insurance companies. Among non-financial shareholders, non-financial companies are the largest shareholders in about $25 \%$ of banks.

In Table 9 Panel B columns (2)-(4) we report the results on the role played by shareholders categories on bank risk-taking. We first analyse the impact of financial versus non-financial shareholders, column (2). The estimated coefficient of the dummy Financial Shareholder is positive and insignificant, suggesting that there is no statistical difference in risk-taking between the two groups. This may be due to the fact that among financial shareholders there might be different incentives towards risk. Therefore, we split financial shareholders into the three categories as defined above: Institutional Investor, Bank and Insurance (column (3)). The estimated coefficient of the dummy Institutional Investor is positive and statistically significant at the 10\% level, suggesting that banks owned by institutional investors seem to take riskier decisions than those with non-financial owners. As a final test, we include also the category of Non-financial company and we use the category Family as base case (column (4)). Overall, our findings provide only weak evidence of the differential role played by shareholder type on risk-taking once we explicitly account for their portfolio diversification. In fact, across all models our proxy of portfolio diversification still remains positive and strongly significant.

\subsection{Shareholder's control}

Previous studies take $10 \%$ of control rights as a threshold to identify large, powerful shareholders who are able to influence a bank's decisions (Caprio et al., 2007; Laeven and Levine, 2009). In our sample, the average (median) ultimate largest shareholder holds more than $40 \%$ (28\%) of control rights, suggesting that most of our banks are controlled by powerful shareholders. Nonetheless, we re-run the baseline model excluding those banks where the ultimate shareholder holds less than $10 \%$ of control rights. Results hold as reported in Table 9 Panel C column (1). They also hold when we exclude shareholders with a control rights threshold of $20 \%$ (column (2)).

\section{Further robustness tests}

Table 10 reports results from a number of additional robustness tests where we use alterative measures of risk-taking and portfolio diversification; we control for the type of bank, for the institutional settings where banks operate, and, finally, we run tests where we exclude Eastern European banks.

\footnotetext{
${ }^{24}$ For instance, a large number of direct shareholders are simply classified as "Financial Company" in both Bankscope and Amadeus.
} 
Table 10

Further robustness tests.

\begin{tabular}{|c|c|c|c|c|c|c|c|c|c|c|}
\hline & $\begin{array}{l}\sigma_{i, R O A} \\
(1) \\
\end{array}$ & $\begin{array}{l}\text { Survival } \\
(2)\end{array}$ & $\begin{array}{l}\text { Ln No. of } \\
\text { Countries } \\
(3)\end{array}$ & $\begin{array}{l}\text { Fraction of } \\
\text { wealth } \\
(4)\end{array}$ & $\begin{array}{l}\text { Dual class } \\
\text { shares } \\
(5)\end{array}$ & $\begin{array}{l}\text { Institutional } \\
\text { investors } \\
(6)\end{array}$ & $\begin{array}{l}\text { Bank type } \\
\text { (7) }\end{array}$ & $\begin{array}{l}\text { Institutional } \\
\text { settings } \\
(8) \\
\end{array}$ & $\begin{array}{l}\text { No Eastern } \\
\text { Europe } \\
(9) \\
\end{array}$ & \\
\hline Ln No. of Firms & $\begin{array}{l}0.0432^{* *} \\
{[0.0271]} \\
\mathbf{1 . 3 1 \%}\end{array}$ & $\begin{array}{l}-0.2212^{* * * *} \\
{[0.0000]} \\
2.95 \%\end{array}$ & & & $\begin{array}{l}0.0580^{* * *} \\
{[0.0116]} \\
\mathbf{4 . 4 7 \%}\end{array}$ & $\begin{array}{l}0.0481^{* * *} \\
{[0.0073]} \\
\mathbf{3 . 7 0 \%}\end{array}$ & $\begin{array}{l}0.0451^{* *} \\
{[0.0105]} \\
\mathbf{3 . 4 8} \%\end{array}$ & $\begin{array}{l}0.0449^{* *} \\
{[0.0128]} \\
\mathbf{3 . 4 6 \%}\end{array}$ & $\begin{array}{l}0.0502^{* * *} \\
{[0.0000]} \\
\mathbf{3 . 8 7 \%}\end{array}$ & \\
\hline Ln No. of Countries & & & $\begin{array}{l}0.0746^{* * *} \\
{[0.0036]} \\
\mathbf{3 . 9 5 \%}\end{array}$ & & & & & & & $\begin{array}{r}x \\
0\end{array}$ \\
\hline Fraction of wealth & & & & $\begin{array}{l}-0.1855^{* * * *} \\
{[0.0003]} \\
\mathbf{3 . 8 1 \%}\end{array}$ & & & & & & 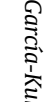 \\
\hline Cash flow rights & $\begin{array}{l}0.0009 \\
{[0.3022]}\end{array}$ & $\begin{array}{l}-0.0060^{* * *} \\
{[0.0048]}\end{array}$ & $\begin{array}{l}0.001 \\
{[0.2378]}\end{array}$ & $\begin{array}{l}0.001 \\
{[0.2157]}\end{array}$ & $\begin{array}{l}0.0007 \\
{[0.5081]}\end{array}$ & $\begin{array}{l}0.0014^{*} \\
{[0.0895]}\end{array}$ & $\begin{array}{l}0.0009 \\
{[0.2840]}\end{array}$ & $\begin{array}{l}0.0012 \\
{[0.1362]}\end{array}$ & $\begin{array}{l}0.0010^{* *} \\
{[0.0336]}\end{array}$ & 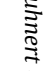 \\
\hline Managerial ownership & $\begin{array}{l}0.0063 \\
{[0.4703]}\end{array}$ & $\begin{array}{l}-0.0047 \\
{[0.9080]}\end{array}$ & $\begin{array}{l}0.001 \\
{[0.8955]}\end{array}$ & $\begin{array}{l}0.0007 \\
{[0.9263]}\end{array}$ & $\begin{array}{l}0.0008 \\
{[0.9201]}\end{array}$ & $\begin{array}{l}0.0018 \\
{[0.8234]}\end{array}$ & $\begin{array}{l}0.0006 \\
{[0.9356]}\end{array}$ & $\begin{array}{l}0.0018 \\
{[0.8203]}\end{array}$ & $\begin{array}{l}0.0032 \\
{[0.6721]}\end{array}$ & $\stackrel{?}{\stackrel{1}{2}}$ \\
\hline Size & $\begin{array}{l}-0.1007^{* * *} \\
{[0.0000]}\end{array}$ & $\begin{array}{l}0.2052^{* * *} \\
{[0.0000]}\end{array}$ & $\begin{array}{l}-0.0323^{*} \\
{[0.0671]}\end{array}$ & $\begin{array}{l}-0.0172 \\
{[0.3253]}\end{array}$ & $\begin{array}{l}-0.0134 \\
{[0.5329]}\end{array}$ & $\begin{array}{l}-0.0303^{*} \\
{[0.0937]}\end{array}$ & $\begin{array}{l}-0.0294^{*} \\
{[0.0938]}\end{array}$ & $\begin{array}{l}-0.0301^{*} \\
{[0.0875]}\end{array}$ & $\begin{array}{l}-0.0232^{* *} \\
{[0.0157]}\end{array}$ & $\begin{array}{l}\bar{Z} \\
\overline{3}\end{array}$ \\
\hline CAR & $\begin{array}{l}2.4841^{* * * *} \\
{[0.0000]}\end{array}$ & $\begin{array}{l}-0.8996 \\
{[0.1373]}\end{array}$ & $\begin{array}{l}-0.7083^{* *} \\
{[0.0192]}\end{array}$ & $\begin{array}{l}-0.6000^{* *} \\
{[0.0459]}\end{array}$ & $\begin{array}{l}-0.6159^{*} \\
{[0.0806]}\end{array}$ & $\begin{array}{l}-0.6516^{* *} \\
{[0.0323]}\end{array}$ & $\begin{array}{l}-0.6188^{* *} \\
{[0.0443]}\end{array}$ & $\begin{array}{l}-0.5299^{*} \\
{[0.0742]}\end{array}$ & $\begin{array}{l}-0.9213^{* * *} \\
{[0.0000]}\end{array}$ & $\stackrel{\tilde{S}}{\Xi}$ \\
\hline & {$[0.0096]$} & [0.0439] & {$[0.0000]$} & {$[0.0000]$} & {$[0.0004]$} & {$[0.0000]$} & {$[0.0000]$} & {$[0.0000]$} & {$[0.0000]$} & $\stackrel{\Xi}{\cong}$ \\
\hline Interest activity & $\begin{array}{l}-0.0654^{* * *} \\
{[0.0002]}\end{array}$ & $\begin{array}{l}-0.0242 \\
{[0.4689]}\end{array}$ & $\begin{array}{l}-0.0251^{*} \\
{[0.0698]}\end{array}$ & $\begin{array}{l}-0.0260 \\
{[0.0616]}\end{array}$ & $\begin{array}{l}-0.0309^{*} \\
{[0.0724]}\end{array}$ & $\begin{array}{l}-0.0227 \\
{[0.1109]}\end{array}$ & $\begin{array}{c}-0.0198 \\
{[0.1477]}\end{array}$ & $\begin{array}{l}-0.0232^{*} \\
{[0.0975]}\end{array}$ & $\begin{array}{l}-0.0460^{* * *} \\
{[0.0000]}\end{array}$ & 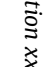 \\
\hline Loan loss provision & $\begin{array}{l}0.9038^{* *} \\
{[0.0227]}\end{array}$ & $\begin{array}{l}3.3906^{* * *} \\
{[0.0015]}\end{array}$ & $\begin{array}{l}0.6656^{*} \\
{[0.0627]}\end{array}$ & $\begin{array}{l}0.6516^{*} \\
{[0.0664]}\end{array}$ & $\begin{array}{l}0.5873 \\
{[0.1511]}\end{array}$ & $\begin{array}{l}0.7644^{* *} \\
{[0.0301]}\end{array}$ & $\begin{array}{l}0.6232^{*} \\
{[0.0817]}\end{array}$ & $\begin{array}{l}0.6428^{*} \\
{[0.0739]}\end{array}$ & $\begin{array}{l}1.3023^{* * *} \\
{[0.0000]}\end{array}$ & 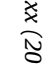 \\
\hline Private dummy & $\begin{array}{l}-0.1303 \\
{[0.1019]}\end{array}$ & $\begin{array}{c}-0.3536 \\
{[0.0897]}\end{array}$ & $\begin{array}{l}-0.0094 \\
{[0.8933]}\end{array}$ & $\begin{array}{l}-0.0063 \\
{[0.9279]}\end{array}$ & $\begin{array}{l}-0.0719 \\
{[0.4354]}\end{array}$ & $\begin{array}{l}-0.0142 \\
{[0.8456]}\end{array}$ & $\begin{array}{l}-0.0022 \\
{[0.9747]}\end{array}$ & $\begin{array}{l}-0.0082 \\
{[0.9097]}\end{array}$ & $\begin{array}{l}-0.1569^{* * *} \\
{[0.0002]}\end{array}$ & $\underset{\substack{x \\
x}}{\tilde{x}}$ \\
\hline Bank type & & & & & & & $\begin{array}{l}0.1475^{* *} \\
{[0.0190]}\end{array}$ & & & $\underset{x}{x}$ \\
\hline Capital stringency index & & & & & & & & $\begin{array}{l}-0.2244^{* *} \\
{[0.0216]}\end{array}$ & & \\
\hline Restrict index & & & & & & & & $\begin{array}{l}-0.0117 \\
{[0.9420]}\end{array}$ & & \\
\hline Creditor rights index & & & & & & & & $\begin{array}{l}0.128 \\
{[0.6544]}\end{array}$ & & \\
\hline Depth of credit information & & & & & & & & $\begin{array}{l}-0.1470 \\
{[0.0569]}\end{array}$ & & \\
\hline
\end{tabular}




\begin{tabular}{|c|c|c|c|c|c|c|c|c|c|}
\hline & $\begin{array}{l}\sigma_{i, R O A} \\
(1)\end{array}$ & $\begin{array}{l}\text { Survival } \\
(2)\end{array}$ & $\begin{array}{l}\text { Ln No. of } \\
\text { Countries } \\
\text { (3) }\end{array}$ & $\begin{array}{l}\text { Fraction of } \\
\text { wealth } \\
\text { (4) }\end{array}$ & $\begin{array}{l}\text { Dual class } \\
\text { shares } \\
(5)\end{array}$ & $\begin{array}{l}\text { Institutional } \\
\text { investors } \\
\text { (6) }\end{array}$ & $\begin{array}{l}\text { Bank type } \\
\text { (7) }\end{array}$ & $\begin{array}{l}\text { Institutional } \\
\text { settings } \\
\text { (8) }\end{array}$ & $\begin{array}{l}\text { No Eastern } \\
\text { Europe } \\
(9)\end{array}$ \\
\hline Financial statement transparency & & & & & & & & $\begin{array}{l}0.2815 \\
{[0.2680]}\end{array}$ & \\
\hline Intercept & $\begin{array}{l}-4.0826^{* * *} \\
{[0.0000]}\end{array}$ & $\begin{array}{l}-2.0211 \\
{[0.1509]}\end{array}$ & $\begin{array}{l}-1.7203^{* *} \\
{[0.0124]}\end{array}$ & $\begin{array}{l}-1.6132^{* *} \\
{[0.0173]}\end{array}$ & $\begin{array}{l}-1.9105^{* *} \\
{[0.0164]}\end{array}$ & $\begin{array}{l}-0.112 \\
{[0.8329]}\end{array}$ & $\begin{array}{l}-1.8861^{* * *} \\
{[0.0049]}\end{array}$ & $\begin{array}{l}-1.4209 \\
{[0.4579]}\end{array}$ & $\begin{array}{l}-1.6530^{* * *} \\
{[0.0000]}\end{array}$ \\
\hline Shareholder fixed effects & Yes & No & Yes & Yes & Yes & Yes & Yes & Yes & Yes \\
\hline Country $\times$ Year fixed effects & Yes & Yes & Yes & Yes & Yes & Yes & Yes & Yes & Yes \\
\hline Adjusted $R$-squared & 0.46 & & 0.32 & 0.32 & 0.30 & 0.33 & 0.32 & 0.323 & 0.10 \\
\hline No. of observations & 4,768 & 1,600 & 4,768 & 4,768 & 3,654 & 4,537 & 4,768 & 4,507 & 3,700 \\
\hline
\end{tabular}

This table reports panel regression results of several robustness tests. In column (1) the dependent variable is $\operatorname{Ln}$ volatility of $R O A\left(\sigma_{i}\right.$ ROA $)$ which is the standard deviation of ROA calculated over five consecutive year overlapping periods, that is, 2000-2004, 2001-2005, 2002-2006, 2003-2007 and 2004-2008. ROA is defined as the ratio of the gross pre-tax profit (including loan loss provisions) to total assets. In column (2) Survival is a binary variable equal to 1 if a bank entering our sample before 2004 survives for at least five years, and 0 otherwise. In columns (3)-(9) the dependent variable is the $L n Z$-score. The Z-score is the ratio of volatility of ROA ( $\left.\sigma_{i, \mathrm{ROA}}\right)$ to the sum of average return on assets (avgROA) and average capital asset ratio (avgCAR). Each component of the Z-score is calculated over five consecutive year overlapping periods, that is, 2000-2004, 2001-2005, 2002-2006, 2003-2007 and 2004-2008. All independent variables are taken at the beginning of the period over which the dependent variables are calculated. Please refer to Table 1 for the definitions of all variables. All regressions include Country $x$ Year fixed effects and all but Survival include also Shareholder fixed effects, and standard errors are correct for heteroskedasticity. The economic impact of each portfolio diversification proxy is reported below the corresponding $p$-value in bold. The economic impact is calculated as the percentage change of the average bank risk-taking in response to a standard deviation increase of the portfolio diversification variable. In the Survival model the economic impact is calculated using the marginal effect of the portfolio diversification variable. $P$-values are reported in brackets.

Report the statistical significance at the $10 \%$ level.

** Report the statistical significance at the 5\% level.

*** Report the statistical significance at the $1 \%$ level. 


\subsection{Alternative dependent variables}

We use two alternative proxies for risk-taking as dependent variable: volatility of ROA $\left(\sigma_{i, R O A}\right)$ alone and Survival. Volatility of ROA is commonly used in the literature as a proxy for firm risk-taking decisions (Faccio et al., 2011; John et al., 2008). It is equal to the standard deviation of ROA calculated over five consecutive year overlapping periods, that is, 2000-2004, 2001-2005, 2002-2006, 2003-2007 and 2004-2008 In the estimations we use its logarithmic transformation to smooth the effect of extreme values. Survival is a dummy equal to 1 if a bank, entering our sample between 1999 and 2004, is still in the sample for at least five years, and zero otherwise. In column (1) we report the results from the panel data analysis with volatility of ROA as dependent variable. The estimated coefficient of portfolio diversification is positive and statistically significant. In column (2) we show the results of the Logit regression where Survival is the dependent variable. Banks controlled by more diversified shareholders are less likely to survive, where the average probability of survival in our sample is equal to $70 \%$.

\subsection{Portfolio diversification measures}

We run three different tests to control for the robustness of our portfolio diversification measures. First, we replace our measures of portfolio diversification with two other alternatives. We control for the diversification of the portfolio across countries ( $L n$ No. of Countries) and find robust evidence supporting our argument that banks with more diversified shareholders are more likely to undertake more risks (column (3)). Further, we use the weight that each investment has in the shareholder's portfolio (Fraction of Wealth, as defined in Section 2.2). The idea is that if a shareholder is not diversified, i.e. she holds one company in her portfolio, the weight of that company will be equal to 1 . In other words, that company will correspond to $100 \%$ of her wealth; the higher the Fraction of Wealth, the higher the portfolio concentration, the lower the expected risk-taking. Indeed, column (4) reports a negative and significant impact on bank risk-taking. ${ }^{25}$

Second, when we calculate the Cash Flow and Control Rights of the largest ultimate shareholder, we are not able to take into account the presence of dual class shares, since this information is not provided in the combined Bankscope-Amadeus database or in the annual financial statements of most of the firms included in the sample. This might create a measurement error in the identification of (ultimate) controlling owners and, therefore, in the construction of our portfolio diversification proxies. We believe that this criticism has little bearing on our identification of the ultimate largest shareholders. In fact, previous studies show that the "dual class shares", as a mechanism to separate cash flow from control rights, have been extensively adopted in only a very few European countries; in others they are forbidden by law, such as in Belgium and Spain (Faccio and Lang, 2002; Nenova, 2003). Further, the European Commission (2007) reports that an increasing number of firms in continental Europe have recently unified their shares into a single class. Based on a study by Pajuste (2005), in only four countries (of our sample) do more than $20 \%$ of publicly traded companies still seem to use such a mechanism at the end of 2001: Sweden (46.3\%), Denmark (36.6\%), Italy (34.6\%), and Finland (23.9\%). Therefore, we believe that this factor should not have an impact on our results. Nonetheless, we analyse again the impact of portfolio diversification on bank risk-taking accounting for this potential bias. As there is no evidence on the extent of dual class shares use among private companies in general, and banks in particular, we conservatively assume that public firms' use of dual class shares mirrors that of private firms (as in Lyandres et al., 2015). We therefore exclude the countries above from our sample and re-run the baseline model. Results in column (5) are similar to our previous findings.

Third, a further limitation of our portfolio diversification measures is that we are not able to capture indirect equity investments (e.g. through mutual funds). One could argue that this may bias our measures downwards, in particular in those markets where the presence of mutual and hedge funds is

\footnotetext{
${ }^{25}$ We also compute, but for brevity do not report, the total number of different 3-digit US SIC sectors in which the largest shareholder invests (No. of sectors). When we use this variable as a measure of portfolio diversification, results are in line with those we present below.
} 
as pervasive as in the US market. However, Lyandres et al. (2015) show how similar measures of portfolio diversification of shareholders in non-financial companies are not affected by this issue. We think it does not play a key role in our tests either. Nevertheless, based on our own identification of bank largest shareholder categories, we exclude those countries in the top tertile of the distribution of institutional investors as bank largest shareholders. ${ }^{26}$ Findings in column (6) are similar to our baseline results. Alternatively, we perform (but not report for brevity) a further test based on the evidence by Ferreira and Matos (2008). They show that institutional investors hold on average less than $20 \%$ of the fraction of market capitalization in Europe. (This figure is substantially higher in the US market at $66 \%$.) We exclude those countries in the top tertile of their institutional investors holding distribution: Sweden, Finland, Netherlands, and Ireland. Findings are very similar to those reported in the paper.

\subsection{Bank type}

We control also for bank type. Previous studies show that commercial banks tend to take more risks than other types of banks, such as saving banks (see, for example, García-Marco and RoblesFernández, 2008). This has been mainly related to a difference in ownership structure, which we already control for. Nonetheless, we include a binary variable equal to one if a bank is a commercial bank and zero otherwise (Bank Type). Most of banks in our sample are commercial banks (66\%). Results in column (7) show that commercial banks do indeed tend to undertake more risks than others. However, this does not affect the impact of portfolio diversification.

\subsection{Institutional settings}

Previous studies take into account a number of national regulations aimed at reducing excessive risk-taking incentives of bank shareholders. For instance, regulations in some countries are more restrictive than others in the assessment of the capital at risk in the bank or in limiting bank non-lending activities, such as market, insurance or real estate activities (e.g. Caprio et al., 2007; Laeven and Levine, 2009).

Further, previous studies show that stronger creditor rights are positively related to higher risktaking by banks, mainly due to the fact that banks tend to lend to a wider set of (riskier) borrowers (Djankov et al., 2007; Houston et al., 2010). At the same time, better information-sharing among creditors should alleviate the ex-ante adverse selection problem in loan screening (Houston et al., 2010).

All our previous tests include Country $x$ Year fixed effects that should already control for the potential influence of such characteristics. Nonetheless, we re-run our baseline model augmented with two proxies for bank regulations as in Barth et al. (2004) and Laeven and Levine (2009): (1) a Capital Stringency Index that measures the regulatory approach to assessing the degree of capital at risk in a bank; and (2) a Restrict Index, which measures the regulatory barriers for banks to undertake nonlending activities. ${ }^{27}$, We further include the Creditor Rights Index from La Porta et al. (1998) and the Depth of Credit Information from Djankov et al. (2007), which measures the information content of the credit information. ${ }^{28}$

Finally, accounting-based risk-taking proxies are likely to be subject to potential criticism of earnings manipulation and differences in accounting standards across countries. Although we use Survival as an alternative measure of risk-taking to limit this concern, we further control for the quality of the accounting standards by augmenting the baseline model with the Financial Statement Transparency from Barth et al. (2006), which measures the transparency of bank financial statement practices. Higher values indicate more transparency. ${ }^{29}$

\footnotetext{
${ }^{26}$ These countries are: Albania, Bulgaria, Denmark, Estonia, Greece, Iceland, Lithuania, Malta, Moldova, Romania, Slovakia, and Sweden.

27 Those studies also used a dummy for the presence of deposit insurance and the minimum capital requirement in each country. We cannot use these two variables here as (when available) they take the same values across all countries in our sample.

28 The Depth of Credit Information measures the availability of credit information from either a public registry or a private bureau to facilitate lending decisions. It ranges from 0 to 6 , with higher values indicating more credit information available.

29 As an alternative we also use the Accounting Standards index from La Porta et al. (1998). Results do not change.
} 
Results when controlling for bank regulations and accounting standards, in column (8), are mostly in line with previous evidence especially for the Capital Stringency Index and Depth of Credit Information (Houston et al., 2010; Laeven and Levine, 2009) while Creditor Rights has no significant impact. More importantly, even after controlling for national regulations and potential accounting manipulation, the effect of portfolio diversification is still positive and highly significant, as in our main findings.

\subsection{Non-Eastern European banks}

One further concern is the inclusion of Eastern European banks in our sample. Recently, Eastern European banks have experienced a period of intense privatization and restructuring and a dramatic growth in lending to private sector that certainly have influenced their risk-taking behaviour (Cottarelli et al., 2005; Lipton et al., 1990). Further, relatively weaker accounting disclosure requirements could make data on Eastern European banks noisier than that for the rest of our sample. Although the inclusion of Country $\times$ Year fixed effects should control for this potential issue as well, we nonetheless re-run the baseline model after excluding these countries. Findings in column (9) on Western European banks confirm our main hypothesis, providing further evidence of the positive and significant relation between portfolio diversification of bank shareholders and bank risk-taking.

\section{Conclusions}

Using the entire universe of Bankscope and Amadeus Top 250,000 we reconstruct the portfolio of the ultimate largest shareholders of publicly traded and privately held European banks between 1999 and 2008. This new dataset shows that the average bank largest shareholder is relatively diversified. We find that $62 \%$ of these largest shareholders is diversified, holding at least two companies in their portfolio. We also find that $23 \%$ have equity positions in at least ten different companies. The average largest shareholder has equity positions in about thirteen different companies. In addition we find that, although negative, the correlation between portfolio diversification and ownership is low and the average diversified shareholder still holds a large fraction of cash flow rights stakes in the bank, above $37 \%$.

These findings are important on two counts. First, due to data limitations, previous studies in banking literature have made different assumptions on the wealth diversification of bank shareholders, often finding contrasting results. Second, our results complement recent evidence in corporate finance literature that shows a more moderate degree of diversification among individuals and investors of non-financial companies.

We use this detailed dataset on portfolio diversification to show that banks controlled by more diversified shareholders tend to undertake more risks than those controlled by less diversified investors. This result is not only statistically significant but also economically important. Across all our proxies, a standard deviation increase of portfolio diversification is likely to increase the insolvency rate of the average bank by almost $3 \%$.

We exploit the panel dimension of our database to estimate all our baseline models with panel data regressions with shareholders fixed effects to reduce the possibility that omitted variable bias and, most importantly, self-selection drive the results. Nonetheless, we undertake a number of further steps to minimize potential concerns of endogeneity.

We use the differences in the institutional settings regulating the ownership of banks across countries both cross-sectionally and in time-series. We observe that the largest shareholders of banks headquartered in countries with less restrictive regulation on the ownership of banks have more diversified portfolios and they take riskier choices than virtually identical banks headquartered in countries with very stringent regulation. Moreover, we find significant changes in bank risk-taking after a shock in the regulatory restrictiveness of ownership of banks. In those countries where the regulation has become more restrictive, after the change the portfolio diversification of largest shareholders significantly decreases and, more importantly, bank risk-taking decreases as well.

Finally, we adopt the instrumental variable technique to extract the "natural" tendency to diversify across investors within the same geographical area. To further address potential reverse causality 
concerns, we use the event of a bank credit rating downgrade as a shock that is likely to affect risktaking. Following a downgrade, we find no significant adjustment in the portfolio diversification of the largest shareholder, which casts doubt on the possibility that reverse causality is affecting our results.

Although we acknowledge the limitations of each of the above tests in tackling the endogeneity issue, all our evidence seems consistent with the argument that largest shareholder portfolio diversification does affect bank risk-taking decisions.

Results in this paper fit well in the recent debate concerning the mechanisms to improve bank risk governance. Our evidence points to the fact that bank largest shareholders seem to play a non-trivial role for the risk-taking decisions of banks. Future research may investigate whether (or not) the risktaking incentives of better diversified shareholders can ultimately lead to improved capital allocation in line with the Schumpeterian view of "creative destruction".

\section{Acknowledgments}

We thank Charles Calomiris (the Editor), the anonymous referee, Bernard Black, Marie Duturdoir, Mara Faccio, Marc Goergen, Christiane Kneer, Maria Fabiana Penas, Stefano Puddu, Luc Renneboog, Natalya Schenck, and seminar participants at Manchester Business School, Northwestern University "2012 Causal Inference Workshop", at the Central Bank of Dominican Republic, at the CambridgeCGIR conference, Cardiff Business School "Corporate Governance and Investment Workshop", FIRS 2013, FMA 2013, and Neuchâtel University for helpful comments. Special thanks to Bobby Foster from Bureau van Dijk and Zhonglun Nie for his excellent research assistance. The usual disclaimers apply.

\section{References}

Acemoglu, D., Zilibotti, F., 1997. Was Prometheus unbound by chance? Risk, Diversification, and Growth. J. Polit. Econ. 105, 709751.

Allen, F., Gale, D., 2004. Competition and financial stability. J. Money, Credit, Bank. 363, 453-480.

Allen, F., Fulghieri, P., Mehran, H., 2011. The value of bank capital and the structure of the banking industry. Rev. Financ. Stud. 24, 971-982.

Almazan, A., Hartzell, J.C., Starks, L.T., 2005. Active Institutional Shareholders and Costs of Monitoring: Evidence from Executive Compensation. Financial Management, Winter, pp. 5-34.

Anderson, R.C., Fraser, D.R., 2000. Corporate control, bank risk taking, and the health of the banking industry. J. Bank. Finance 248, 1383-1398.

Barber, B.M., Odean, T., 2000. Trading is hazardous to your wealth: the common stock investment performance of individual investors. J. Finance 552, 773-806.

Barry, T.A., Lepetit, L., Tarazi, A., 2011. Ownership structure and risk in publicly held and privately owned banks. J. Bank. Finance 35, 1327-1340.

Barth, J.R., Caprio Jr., G., Levine, R., 2004. Bank regulation and supervision: what works best? J. Financ. Intermed. 13, $205-248$.

Barth, J.R., Caprio Jr., G., Levine, R., 2006. Rethinking Bank Regulation: Till Angels Govern. Cambridge University Press, Cambridge, MA.

Barth, J.R., Caprio Jr., G., Levine, R., 2008. Bank regulations are changing: for better or worse? Compar. Econ. Stud. 50, $537-563$.

Barth, J.R., Caprio Jr., G., Levine, R., 2013. Bank regulations and supervision in 180 countries from 1999 to 2011. J. Financ. Econ. Policy 5, 111-220.

Basel Committee on Banking Supervision, 2010. The Basel Committee's Response to the Financial Crisis: Report to the G20. Bank for International Settlements.

Baumol, W., Litan, R., Schramm, C., 2007. Good Capitalism, Bad Capitalism, and the Economics of Growth and Prosperity. Yale University Press, New Haven.

Beck, T., Brown, M., in press. Foreign bank ownership and household credit. J. Financ. Intermed., in press.

Beltratti, A., Stulz, R.M., 2012. The credit crisis around the globe: why did some banks perform better? J. Financ. Econ. 105, 1-17.

Bennedsen, M., Nielsen, K.M., 2010. Incentive and entrenchment effects in european ownership. J. Bank. Finance 34, $2212-2229$.

Bennett, J.A., Sias, R.W., Starks, L.T., 2003. Green pastures and the impact of dynamics institutional preferences. Rev. Financ. Stud. 16, 1203-1238.

Berger, A.N., Clarke, G.R.G., Cull, R., Klapper, L.F., Udell, G.F., 2005. Corporate governance and bank performance: a joint analysis of the static, selection, and dynamic effects of domestic, foreign, and state ownership. J. Bank. Finance 29, 2179-2221.

Berger, A.N., Hasan, I., Klapper, L.F., 2004. Further Evidence on the link between finance and growth: an international analysis of community banking and economic performance. J. Financ. Serv. Res. 25, 169-202.

Berger, A.N., Klapper, L.F., Martinez Peria, M.S., Zaidi, R., 2008. Bank ownership type and banking relationships. J. Financ. Intermed. 17, 37-62.

Bertrand, M., Metha, P., Mullainathan, S., 2002. Ferreting out tunneling: an application to Indian business groups. Quart. J. Econ. 117, 121-148.

Bodnaruk, A., Kendel, E., Massa, M., Simonov, A., 2008. Shareholder diversification and the decision to go public. Rev. Financ. Stud. 21, 2769-2824. 
Bound, J., Jaeger, D.A., Baker, R.M., 1995. Problems with instrumental variables estimation when the correlation between the instruments and the endogenous explanatory variable is weak. J. Am. Stat. Assoc. 90, 443-450.

Boyd, J.H., De Nicoló, G., 2005. The theory of bank risk taking and competition revisited. J. Finance 603, $1329-1343$.

Boyd, J., Graham, S., Hewitt, R., 1993. Bank holding company mergers with nonbank financial firms: effects on the risk of failure. J. Bank. Finance 171, 43-63.

Boyd, J.H., Prescott, E.C., 1986. Financial intermediary-coalitions. J. Econ. Theory 38, $211-232$.

Boyd, J.H., Runkle, D.E., 1993. Size and performance: testing the predictions of banking firms of theory. J. Monetary Econ. 311, 47-67.

Brickley, J.A., Lease, R.C., Smith Jr., R.C., 1988. Ownership structure and voting on antitakeover amendments. J. Financ. Econ. 20, 267-291.

Buch, C.M., Eickmeier, S., Prieto, E., 2011. In Search for Yield? Survey-based Evidence on Bank Risk Taking. Deutsche Bundesbank Discussion Paper Series 10/2011.

Bushee, B.J., 1998. The influence of institutional investors on Myopic R\&D investment behavior. Account. Rev. 73, 305-333.

Campbell, J.Y., Lettau, M., Malkiel, B.G., Xu, Y., 2001. Have individual stocks become more volatile? An empirical exploration of idiosyncratic risk. J. Finance 561, 1-43.

Caprio, G., Laeven, L., Levine, R., 2007. Governance and bank valuation. J. Financ. Intermed. 16, 584-617.

Cebenoyan, A.S., Cooperman, E.S., Register, C.A., 1999. Ownership structure, charter value, and risk-taking behavior for thrifts. Financ. Manage. 28, 43-60.

Chen, X., Harford, J., Li, K., 2007. Monitoring: which institutions matter? J. Financ. Econ. 86, 279-305.

Cheng, I., Hong, H., Scheinkman, J.A., 2015. Yesterday’s heroes: compensation and risk at financial firms. J. Finance 70, 839-879.

Claessens, S., Djankov, S., Lang, L.H.P., 2000. The separation of ownership and control in East Asian Corporations. J. Financ. Econ. $58,81-112$.

Claessens, S., Djankov, S., Fan, J.P.H., Lang, L.H.P., 2002. Disentangling the incentive and entrenchment effects of large shareholdings. J. Finance 57, 2741-2771.

Claessens, S., van Horen, N., 2012. Being a foreigner among domestic banks: asset or liability? J. Bank. Finance 36, $1276-1290$.

Clarke, G., Cull, R., Peria, M., 2006. Foreign banks participation and access to credit across firms in developing countries. J. Compar. Econ. 34, 774-795.

Cooper, I.A., Kaplanis, E., 1994. Home bias in equity portfolios, inflation hedging, and international capital market equilibrium. Rev. Financ. Stud. 71, 45.

Cottarelli, C., Dell'Ariccia, G., Vladkova-Hollar, I., 2005. Early birds, late risers, and sleeping beauties: bank credit growth to the private sector in central and Eastern Europe and in the Balkans. J. Bank. Finance 291, 83-104.

Coval, J.D., Moskowitz, T.J., 1999. Home bias at home: local equity preference in domestic portfolios. J. Finance 54, $2045-2074$.

Crystal, J.S., Dages, B.G., Goldberg, L.S., 2002. Has Foreign Bank Entry Led to Sounder Banks in Latin America? In: Current Issues in Economics and Finance, Federal Reserve Bank of New York 8.

de Haan, J., Vlahu, R., 2013. Corporate Governance of Banks: A Survey. DNB Working Paper 386.

De Nicoló, G., Loukoianova, E., 2007. Bank Ownership, Market Structure and Risk. IMF Working Paper WP/07/215.

Degryse, H., Havrylchyk, O., Jurzyk, E., Kozak, S., 2009. Foreign Bank Entry and Credit Allocation in Emerging Markets. IMF Working Paper WP/09/270.

Demirgüç-Kunt, A., Huizinga, H., 2010. Bank activity and funding strategies: the impact on risk and returns. J. Financ. Econ. 983, 626-650.

Demsetz, H., Lehn, K., 1985. The structure of corporate ownership: causes and consequences. J. Polit. Econ. 936, $1155-1177$.

Diamond, D.W., 1984. Financial intermediation and delegated monitoring. Rev. Econ. Stud. 51, $393-414$.

Djankov, S., McLiesh, C., Shleifer, A., 2007. Private credit in 129 countries. J. Financ. Econ. 84, $299-329$.

Drakos, A.A., Kouretas, G.P., Tsoumas, C., 2014. Ownership, Interest Rates and Bank Risk-taking in Central and Eastern European Countries. Int. Rev. Financ. Anal., in press.

Erkens, D.A., Hung, M., Matos, P., 2012. Corporate Governance in the 2007-2008 financial crisis: evidence from financial institutions worldwide. J. Corp. Finance 18, 389-411.

European Banking Federation, 2011. EU Banking Sector: Facts and Figures.

European Commission, 2007. Report on the Proportionality Principle in the European Union.

Faccio, M., Lang, L.H.P., 2002. The ultimate ownership of Western European corporations. J. Financ. Econ. 65, $365-395$.

Faccio, M., Marchica, M.-T., Mura, R., 2011. Large shareholder diversification and corporate risk-taking. Rev. Financ. Stud. 2411, $3601-3641$.

Ferreira, M., Matos, P., 2008. The colors of investors' money: the role of institutional investors around the world. J. Financ. Econ. 88, 499-533.

French, K.R., Poterba, J.M., 1991. Investor diversification and international equity markets. Am. Econ. Rev. 812, $222-226$.

García-Marco, T., Robles-Fernández, M., 2008. Risk-taking behaviour and ownership in the banking industry: the Spanish evidence. J. Econ. Bus. 604, 332-354.

Gaspar, J.-M., Massa, M., Matos, P., 2005. Shareholder investment horizons and the market for corporate control. J. Financ. Econ. 76, 135-165.

Giannetti, M., Ongena, S., 2012. "Lending by example”: direct and indirect effects of foreign banks in emerging markets. J. Int. Econ. 86, 167-180.

Goetzmann, W.N., Kumar, A., 2008. Equity portfolio diversification. Rev. Finance 123, 433-463.

Gormley, T., 2010. The impact of foreign bank entry in emerging markets: evidence from India. J. Financ. Intermed. $19,26-51$.

Gorton, G., Rosen, R., 1995. Corporate control, portfolio choice, and the decline of banking. J. Finance 50, $1377-1420$.

Hellmann, T.F., Murdock, K.C., Stiglitz, J.E., 2000. Moral Hazard in banking, and prudential liberalization, regulation: are capital requirements enough? Am. Econ. Rev. 901, 147-165.

Hotchkiss, E.S., Strickland, D., 2003. Does shareholder composition matter? Evidence from the market reaction to corporate earnings announcements. J. Finance 58, 1469-1498.

Houston, J.F., Lin, C., Lin, P., Ma, Y., 2010. Creditor rights, information sharing, and bank risk taking. J. Financ. Econ. 93 , 485-512. 
Jensen, M., Meckling, W., 1976. Theory of the firm: managerial behavior, agency costs, and capital structure. J. Financ. Econ. 34, 305-360.

John, K., Litov, L., Yeung, B., 2008. Corporate governance and risk-taking. J. Finance 63, 1679-1728.

Johnson, S., La Porta, R., Lopez-de-Silanes, F., Shleifer, A., 2000. Tunneling. Am. Econ. Rev. 90, 22-27.

Karhunen, J., Keloharju, M., 2001. Share ownership in Finland 2000. Finnish J. Bus. Econ. 50, 188-226.

Keeley, M.C., 1990. Deposit insurance, risk, and market power in banking. Am. Econ. Rev. 80, 1183-1200.

Knopf, J.D., Teall, J.L., 1996. Risk-taking behavior in the U.S. thrift industry: ownership structure and regulatory changes. J. Bank. Finance 20, 1329-1350.

La Porta, R., Lopez-de-Silanes, F., Shleifer, A., Vishny, R.W., 1998. Law and finance. J. Polit. Econ. 106, 1113-1155.

La Porta, R., Lopez-de-Silanes, F., Shleifer, A., 2002. Government ownership of banks. J. Finance 57, 265-301.

Laeven, L., Levine, R., 2009. Bank governance, regulation and risk taking. J. Financ. Econ. 93, 259-275.

Levine, R., 1997. Financial development and economic growth: views and agenda. J. Econ. Literat. 35, 688-726.

Levine, R., 2005. Finance and Growth: Theory and Evidence. In: Aghion, P., Durlauf, S.N. (Eds.), Handbook of Economic Growth Volume 1A.

Lipton, D., Sachs, J., Fischer, S., Kornai, J., 1990. Creating a Market Economy in Eastern Europe: The Case of Poland; Comments and Discussion. Brookings Papers on Economic Activity 1990, pp. 75-147.

Lyandres, E., Marchica, M.-T., Michaely, R., Mura, R., 2015. Owners' Portfolio Diversification and Firm Investment: Evidence from Public and Private Firms. Johnson School Cornell University Working Paper.

Merton, R.C., 1992. Continuous-Time Finance. Blackwell Publishing Ltd.

Mian, A., 2006. Distance constraints: the limits of foreign lending to poor economies. J. Finance 61, 1465-1505.

Morck, R., Wolfenzon, D., Yeung, B., 2005. Corporate governance, economic entrenchment and growth. J. Econ. Literat. 43, 655720.

Morck, R., Yavuz, V.M., Yeung, B., 2011. Banking system control, capital allocation, and economy performance. J. Financ. Econ. $100,264-283$.

Nenova, T., 2003. The value of corporate voting rights and control: a cross-country analysis. J. Financ. Econ. 68, $325-351$.

Ongena, S., Popov, A., Udell, G.F., 2013. "When the Cat's Away the Mice Will Play": does regulation at home affect bank risktaking abroad? J. Financ. Econ. 108, 727-750.

Pajuste, A., 2005. Determinants and Consequences of the Unification of Dual-Class Shares. Working Paper Series No. 465.

Parrino, R., Poteshman, A.M., Weisbach, M.S., 2005. Measuring investment distortions when risk-averse managers decide whether to undertake risky projects. Financ. Manage. 34, 21-60.

Rosenbaum, P.R., Rubin, D.B., 1983. The central role of the propensity score in observational studies for causal effects. Biometrika 70, 41-55.

Roy, A.D., 1952. Safety first and the holding of assets. Econometrica 203, 431-449.

Saunders, A., Strock, E., Travlos, N.G., 1990. Ownership structure, deregulation, and bank risk taking. J. Finance 45, 643-654.

Schumpeter, J.A., 1934. The Theory of Economic Development. An Inquiry into Profits, Capital, Credit, Interest, and the Business Cycle. Cambridge: Harvard University Press.

Sorensen, B., Wu, Y.-T., Yosha, O., Zhu, Y., 2007. Home bias and international risk sharing: twin puzzles separated at birth. J. Int. Money Finance 264, 587-605.

Staiger, D., Stock, J.H., 1997. Instrumental variables regression with weak instruments. Econometrica 65, 557-586.

Statman, M., 1987. How many stocks make a diversified portfolio? J. Financ. Quantitat. Anal. 223, 353-363.

Sullivan, R.J., Spong, K.R., 2007. Manager wealth concentration, ownership structure, and risk in commercial banks. J. Financ. Intermed. 162, 229-248.

Taboada, A.G., 2011. The impact of changes in bank ownership structure on the allocation of capital: international evidence. J. Bank. Finance 35, 2528-2543.

Wooldridge, J.M., 2002. Econometric Analysis of Cross Section and Panel Data. MIT Press, Cambridge.

Wurgler, J., 2000. Financial markets and the allocation of capital. J. Financ. Econ. 58, 187-214. 